\title{
Summary of Biological and Contaminant Investigations Related to Stream Water Quality and Environmental Setting in the Upper Colorado River Basin, 1938-95
}

By JEFFREY R. DEACON and VERLIN C. STEPHENS

U.S. GEOLOGICAL SURVEY

Water-Resources Investigations Report 96-4172

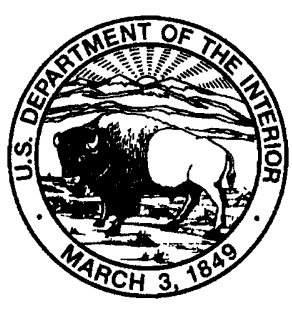




\title{
U.S. DEPARTMENT OF THE INTERIOR \\ BRUCE BABBITT, Secretary
}

\author{
U.S. GEOLOGICAL SURVEY \\ Gordon P. Eaton, Director
}

The use of firm, trade, and brand names in this report is for identification purposes only and does not constitute endorsement by the U.S. Geological Survey.

For additional information write to:

Copies of this report can be purchased from:

District Chief

U.S. Geological Survey

Box 25046, Mail Stop 415

Denver Federal Center

Denver, CO 80225-0046
U.S. Geological Survey

Branch of Information Services

Box 25286

Denver, CO 80225-0286 


\section{FOREWORD}

The mission of the U.S. Geological Survey (USGS) is to assess the quantity and quality of the earth resources of the Nation and to provide information that will assist resource managers and policymakers at Federal, State, and local levels in making sound decisions. Assessment of water-quality conditions and trends is an important part of this overall mission.

One of the greatest challenges faced by water-resources scientists is acquiring reliable information that will guide the use and protection of the Nation's water resources. That challenge is being addressed by Federal, State, interstate, and local water-resource agencies and by many academic institutions. These organizations are collecting water-quality data for a host of purposes that include: compliance with permits and water-supply standards; development of remediation plans for a specific contamination problem; operational decisions on industrial, wastewater, or water-supply facilities; and research on factors that affect water quality. An additional need for water-quality information is to provide a basis on which regional and national-level policy decisions can be based. Wise decisions must be based on sound information. As a society we need to know whether certain types of water-quality problems are isolated or ubiquitous, whether there are significant differences in conditions among regions, whether the conditions are changing over time, and why these conditions change from place to place and over time. The information can be used to help determine the efficacy of existing water-quality policies and to help analysts determine the need for and likely consequences of new policies.

To address these needs, the Congress appropriated funds in 1986 for the USGS to begin a pilot program in seven project areas to develop and refine the National Water-Quality Assessment (NAWQA) Program. In 1991, the USGS began full implementation of the program. The NAWQA Program builds upon an existing base of water-quality studies of the USGS, as well as those of other Federal, State, and local agencies. The objectives of the NAWQA Program are to:

-Describe current water-quality conditions for a large part of the Nation's freshwater streams, rivers, and aquifers.

-Describe how water quality is changing over time.

-Improve understanding of the primary natural and human factors that affect water-quality conditions. This information will help support the development and evaluation of management, regulatory, and monitoring decisions by other Federal, State, and local agencies to protect, use, and enhance water resources.

The goals of the NAWQA Program are being achieved through ongoing and proposed investigations of 60 of the Nation's most important river basins and aquifer systems, which are referred to as study units. These study units are distributed throughout the Nation and cover a diversity of hydrogeologic settings. More than two-thirds of the Nation's freshwater use occurs within the 60 study units and more than two-thirds of the people served by public water-supply systems live within their boundaries.

National synthesis of data analysis, based on aggregation of comparable information obtained from the study units, is a major component of the program. This effort focuses on selected water-quality topics using nationally consistent information. Comparative studies will explain differences and similarities in observed water-quality conditions among study areas and will identify changes and trends and their causes. The first topics addressed by the national synthesis are pesticides, nutrients, volatile organic compounds, and aquatic biology. Discussions on these and other water-quality topics will be published in periodic summaries of the quality of the Nation's ground and surface water as the information becomes available.

This report is an element of the comprehensive body of information developed as part of the NAWQA Program. The program depends heavily on the advice, cooperation, and information from many Federal, State, interstate, Tribal, and local agencies and the public. The assistance and suggestions of all are greatly appreciated. 



\section{CONTENTS}

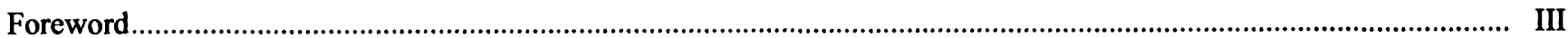

Abstract

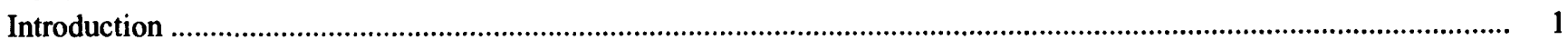

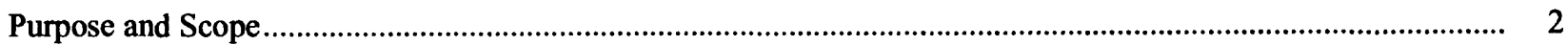

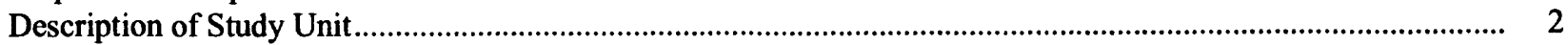

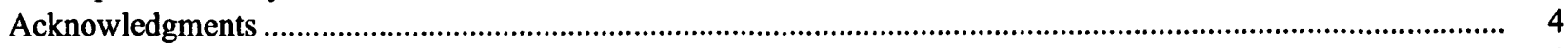

Inventory of Biological and Contaminant Investigations of Streams..........................................................................

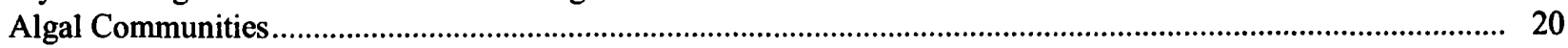

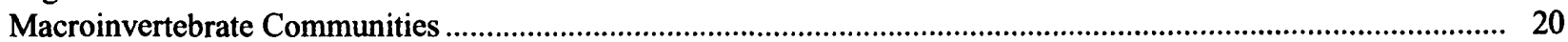

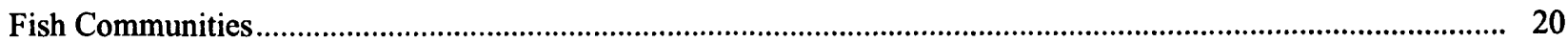

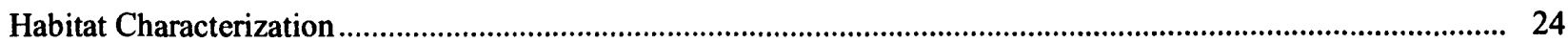

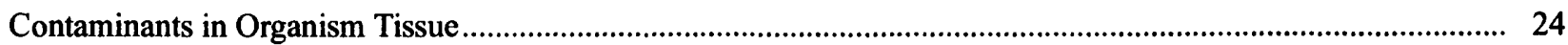

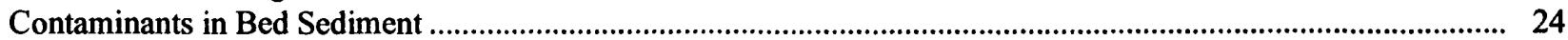

Effects of Environmental Setting on Biological Communities in Streams ............................................................. 28

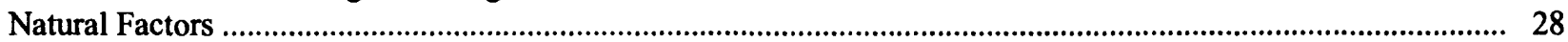

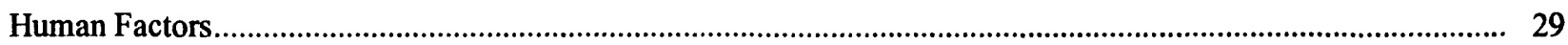

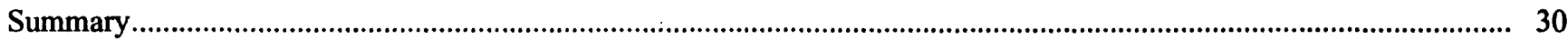

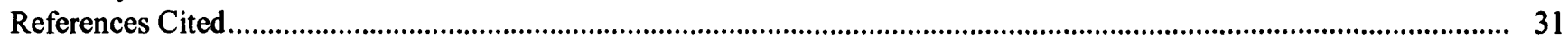

\section{FIGURES}

1-7. Maps showing:

1. Location of the Upper Colorado River Basin study unit, physiographic provinces, and major streams........... 3

2. General locations of sites sampled for algal-community investigations................................................. 21

3. General locations of sites sampled for macroinvertebrate-community investigations .................................. 22

4. General locations of sites sampled for fish-community investigations................................................. 23

5. General locations of sites sampled for habitat-characterization investigations ........................................... 25

6. General locations of sites sampled for contaminants in organism-tissue investigations ................................ 26

7. General locations of sites sampled for contaminants in bed-sediment investigations.................................. 27

\section{TABLES}

1. Literature citations indexed by type of biological or contaminant investigation, physiographic province, and predominant land use in the Upper Colorado River Basin study unit

2. Major aquatic biological taxa in the Southern Rocky Mountains and Colorado Plateau physiographic provinces of the Upper Colorado River Basin study unit 


\begin{tabular}{rll}
\hline Multiply & By & To obtaln \\
\hline foot $(\mathrm{ft})$ & 0.3048 & meter \\
inch per year (in/yr) & 25.4 & millimeter per year \\
mile $(\mathrm{mi})$ & 1.609 & kilometer \\
square mile ( $\left.\mathrm{mi}^{2}\right)$ & 2.59 & square kilometer \\
\hline
\end{tabular}

Degree Fahrenheit $\left({ }^{\circ} \mathrm{F}\right)$ may be converted to degree Celsius $\left({ }^{\circ} \mathrm{C}\right)$ by using the following equation:

$$
{ }^{\circ} \mathrm{C}=5 / 9\left({ }^{\circ} \mathrm{F}-32\right)
$$

Sea level: In this report, "sea level" refers to the National Geodetic Vertical Datum of 1929 (NGVD of 1929)-a geodetic datum derived from a general adjustment of the first-order level nets of both the United States and Canada, formerly called Sea Level Datum of 1929. 


\section{Summary of Biological and Contaminant Investigations Related to Stream Water Quality and Environmental Setting in the Upper Colorado River Basin, 1938-95}

\author{
By Jeffrey R. Deacon and Verlin C. Stephens
}

\section{ABSTRACT}

As part of the U.S. Geological Survey's National Water-Quality Assessment (NAWQA) program, an inventory of the biological and contaminant investigations for the Upper Colorado River Basin study unit was conducted. To enhance the sampling design for the biological component of the program, previous studies about the ecology of aquatic organisms and contaminants were compiled from computerized literature searches of biological data bases and by contacting other Federal, State, and local agencies. Biological and contaminant investigations that have been conducted throughout the basin since 1938 were categorized according to four general categories of biological investigations and two categories of contaminant investigations: algal communities, macroinvertebrate communities, fish communities, habitat characterization, contaminants in organism tissue, and contaminants in bed sediment. The studies were identified by their locations in two physiographic provinces, the Southern Rocky Mountains and the Colorado Plateau, and by the predominant land use in the area of the investigation. Studies on algal communities and contaminants in organism tissue and in bed sediment are limited throughout the basin. Studies on macroinvertebrate and fish communities and habitat characterization are the most abundant in the study unit. Natural and human factors can affect biological communities and their composition. Natural factors that affect background water-quality conditions are physiography, climate, geology, and soils. Algae, macroinvertebrates, and fish that are present in the
Southern Rocky Mountains and the Colorado Plateau physiographic provinces vary with altitude and physical environment. Green algae and diatoms are predominant in the higher altitude streams, and blue-green, golden-brown, and green algae are predominant in the lower altitude streams. Caddisflies, mayflies, and stoneflies are the dominant macroinvertebrates in the higher altitudes, whereas aquatic worms, leeches, and dragonflies are more common at lower altitudes. Cold-water species, such as trout, are present at the higher altitudes, and warmer water species, such as catfish, carp, and suckers, are predominant at the lower altitudes. Human factors that affect water-quality conditions are mining, urbanization, agriculture, and hydrologic modifications. Mining areas can be depleted of organisms or contain a low diversity of species. Acid-tolerant algae, such as certain species of green algae and diatoms, and metal-tolerant caddisflies can be present in mining areas. Urbanized areas are located in the Southern Rocky Mountains and in the Colorado Plateau and contain species characteristic of the physiographic provinces. Agricultural areas contain species, such as blue-green algae, aquatic worms, suckers, and carp, that can tolerate organic enrichment, sedimentation, and lower concentrations of dissolved oxygen.

\section{INTRODUCTION}

The National Water-Quality Assessment (NAWQA) program is a long-term program by the U.S. Geological Survey (USGS) designed to describe 
the status and trends in the quality of the Nation's surface- and ground-water resources and to provide an understanding of the natural and human factors that can affect the quality of these resources (Leahy and others, 1990). The program, which consists of 60 study units, is interdisciplinary and integrates chemical, physical, and biological data to assess the Nation's water quality at local, regional, and national levels (Meador and Gurtz, 1994). In 1991, the USGS began full implementation of the NAWQA program. The Upper Colorado River Basin (UCOL) study unit was in the second group of 20 NAWQA study units selected in 1994 for implementation of the program. The overall goals of the NAWQA program are to (1) provide a nationally consistent description of current water-quality conditions for a large part of the Nation's water resources; (2) define long-term trends in water quality; and (3) identify, describe, and explain, to the extent possible, the major factors that affect water-quality conditions and trends.

The program focuses on a broad spectrum of constituents and sampling approaches for surface water, including information on (1) biological investigations (algae, macroinvertebrate, and fish communities); (2) stream habitat characterization (Gurtz, 1994); and (3) trace-element and organic contaminants in organism tissue and bed sediment. This information is integrated, as much as possible, with the surfacewater-quality data that include discharge, specific conductance, temperature, $\mathrm{pH}$, dissolved oxygen and concentrations of suspended sediment, inorganic constituents (major ions, nutrients, and trace elements), radionuclides, and organic contaminants in water.

The ecology of biological communities and contaminants in organism tissue and in bed sediment are two biological components used in the NAWQA program to provide multiple lines of evidence (chemical, physical, and biological) for the assessment of water quality. By linking the various components of water quality at various spatial scales, the NAWQA program can provide the kinds of information needed to generate policies and management actions that improve the Nation's water resources (Meador and Gurtz, 1994). The resulting information then can be used to design biological sampling strategies to fill in gaps in the biological and contaminant data and to effectively address critical water-quality issues in the UCOL study unit.
Biological components are useful indicators of water quality because biota respond to a variety of natural and human environmental effects, including stresses from point and nonpoint sources, toxic effluents, enriched organic effluents, extreme flows, and habitat degradation. Biota also provide spatial and temporal information and, in many studies, are more sensitive indicators of environmental change than are other media (Gurtz, 1994). Biological communities, including algae, macroinvertebrate, and fish communities; habitat characterization; and contaminants in organism tissue and in bed sediment are factors assessed by the UCOL study unit. The first step in the implementation of the biological component of the NAWQA program for the UCOL study unit is an inventory of existing biological and contaminant information.

\section{Purpose and Scope}

This report (1) identifies sources of biological and contaminant information in the UCOL study unit; (2) broadly summarizes existing information about biological and contaminant investigations; (3) discusses gaps in biological and contaminant information for the basin; and (4) categorizes this information according to the environmental setting.

The data source for this report was a subset of references compiled from a computerized bibliographic search of 21 data bases (Bauch and Apodaca, 1995). Additional information was provided by several Federal and State agencies, including the U.S. Fish and Wildlife Service, U.S. Environmental Protection Agency, National Park Service, Bureau of Reclamation, Colorado Division of Wildlife, Colorado Water Resources Research Institute; and by local universities.

\section{Description of Study Unit}

The UCOL study unit has varied climate, geology, topography, and hydrology. The study unit has a drainage area of about $17,800 \mathrm{mi}^{2}$. The primary river in the study unit, the Colorado River, originates in the mountains of central Colorado and flows about $230 \mathrm{mi}$ southwest into Utah (fig. 1). The headwaters of the Colorado River and most of its tributaries originate in the mountains that form the eastern and 
southern boundaries of the study unit (Driver, 1994). The major tributaries to the Colorado River in the study unit are the Blue, Eagle, Roaring Fork, and Gunnison Rivers.

The UCOL study unit is divided almost equally into two physiographic provinces - the Southern
Rocky Mountains in the eastern part and the Colorado Plateau in the western part (Apodaca and others, 1996). The climate varies from alpine conditions in the east to semiarid in the west. Precipitation is highly variable throughout the study unit and ranges from more than $50 \mathrm{in} / \mathrm{yr}$ in the higher altitudes to less than

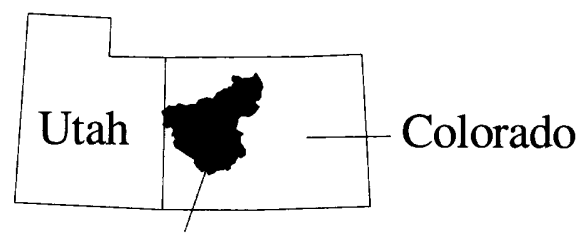

Upper Colorado River Basin

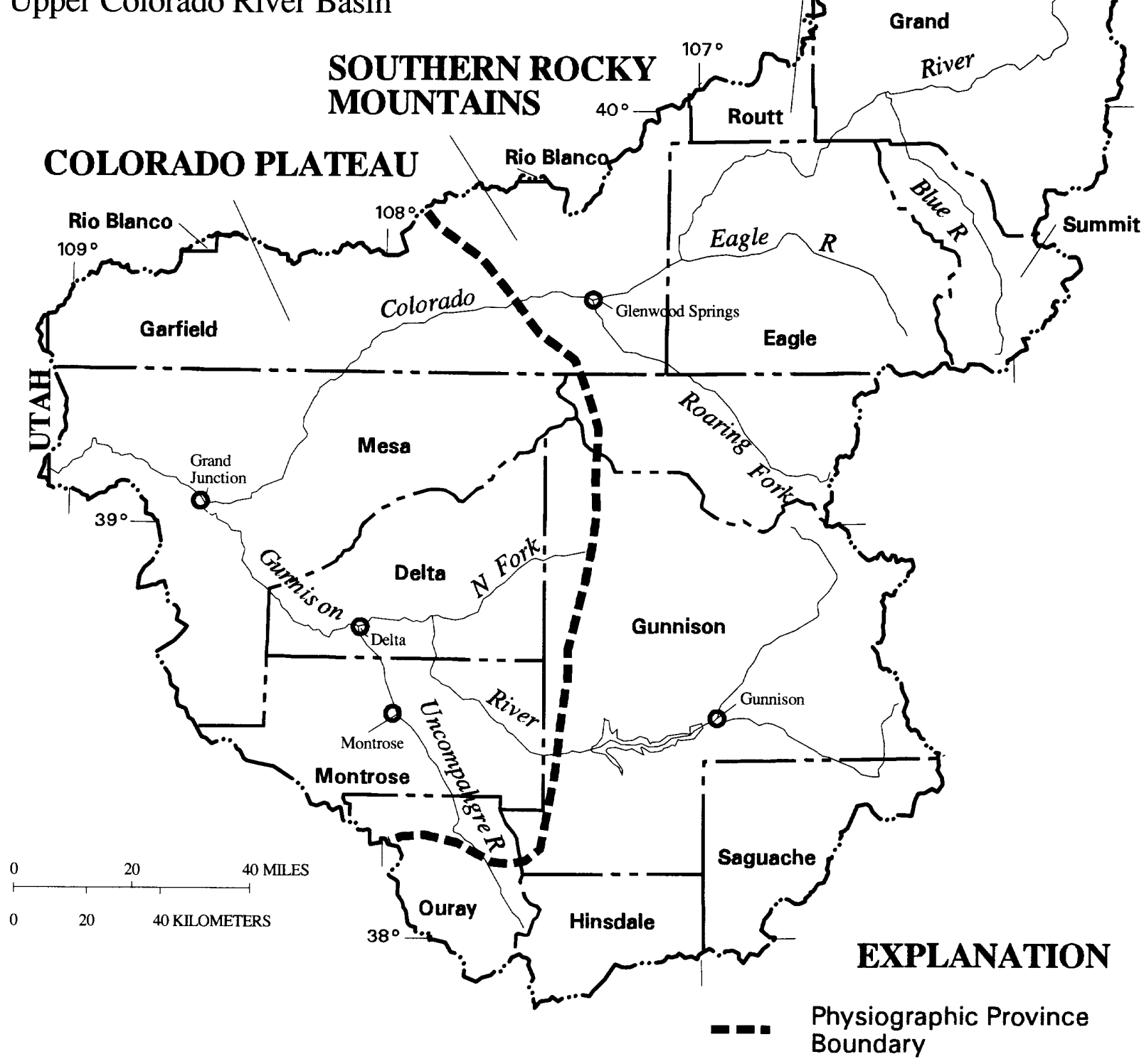

Figure 1. Location of the Upper Colorado River Basin study unit, physiographic provinces, and major streams. 
$10 \mathrm{in} / \mathrm{yr}$ in the lower altitudes of the western valleys. Temperature in the study unit ranges from -30 to $110^{\circ} \mathrm{F}$. The geology primarily consists of rocks of Precambrian age, stratified sedimentary rocks, and alluvial deposits. The topography in the eastern part of the study unit consists of north-northwest-trending mountains that range in altitude from 11,000 to more than $14,000 \mathrm{ft}$. The western part of the study unit generally consists of high plateaus with altitudes ranging from 5,500 to $8,500 \mathrm{ft}$, bordered by steep cliffs along valleys. The altitude of the valleys near the Colorado-Utah State line is about 4,300 ft.

Predominant land uses in the UCOL study unit are mining, urbanization, and agriculture. Past and present mining activities have included the extraction of metals (copper, gold, lead, molybdenum, nickel, silver, vanadium, and zinc) and energy fuels (coal, gas, oil, and uranium). Urbanization is one of the smaller land uses in the mostly rural areas of the study unit. A number of urban areas are associated with growth resulting from the expansion of the ski industry and from energy development in the 1980's (Apodaca and others, 1996). Agriculture is the traditional land use in the Colorado Plateau and includes production of crops such as alfalfa, fruits, grains, hay, and vegetables.

Hydrologic modifications occur throughout the study unit. The principal water use in the UCOL study unit is irrigation, which accounts for about 97 percent of the offstream-water use. The remaining 3 percent is accounted for by the following, in order of decreasing water use: livestock, domestic, power, industrial, commercial, and mining (Apodaca and others, 1996).

\section{Acknowledgments}

The authors thank April Kobayashi and Joyce Dickey, USGS, for their assistance in retrieval of information. The authors also thank the members of the UCOL NAWQA Liaison Committee for their cooperation in providing information and data about the basin. We would especially like to thank Richard Krueger from the U.S. Fish and Wildlife Service, Barbara Horn from the Colorado Division of Wildlife, and Lynn Cudlip from the National Park Service for providing information and data for this report.

\section{INVENTORY OF BIOLOGICAL AND CONTAMINANT INVESTIGATIONS OF STREAMS}

One-hundred-twenty-six biological and contaminant investigations that relate to water quality in the UCOL study unit were grouped into six categories corresponding to the biological components of the NAWQA program: algae, macroinvertebrates, fish, habitat characterization, contaminants in organism tissue, and contaminants in bed sediments. Information about each biological and contaminant component is essential to understand water quality in the study unit. Biological and contaminant investigations in the study unit are listed by the category of investigation and their locations in the two physiographic provinces (table 1). Information about the predominant land use, water-chemistry data, and general description and locations of biological or contaminant investigations also are listed in table 1. Studies that had land-use information from sampling sites on streams that were unaffected by human activity or conducted to establish baseline data were defined as background. Studies that had sampling sites in more than one land-use category (for example, in mining, urban, and agricultural land uses) were defined as mixed land-use studies. Studies that had stream reaches directly affected by various water uses or by hydrologic modification, such as dams and canals, also were categorized in the land-use column (Hyd) in table 1. Several of the studies were not applicable (NA) to a predominant land use, but contained pertinent, generalized information about biological characteristics of the study unit. If an investigation had waterchemistry data collected in addition to the biological and contaminant data, an X was placed in the "Waterchemistry data" column in table 1 . This information was provided because integration of biological and water-chemistry data can be a useful tool in waterquality analysis and because integrated information is a major component of the NAWQA program.

An important aspect of the NAWQA program is to understand the effects of land use on water quality. The objectives of the studies listed in table 1 might not relate to the effects of land use on water quality; but, the inventory of these studies according to land use can help in the overall water-quality sampling design of the UCOL study unit and in filling in some of the gaps in biological data. Data collected during many of the investigations were from both physiographic 


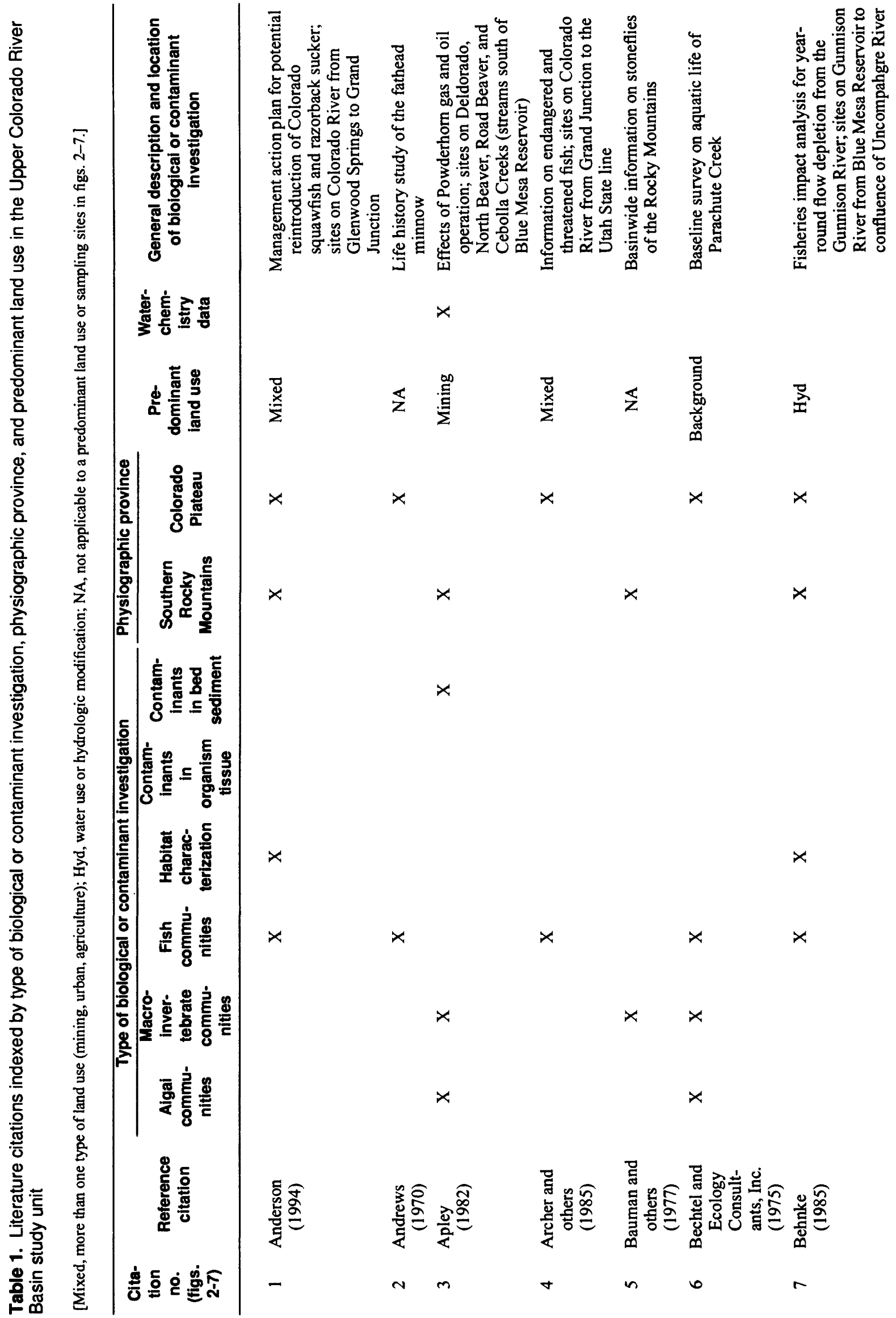




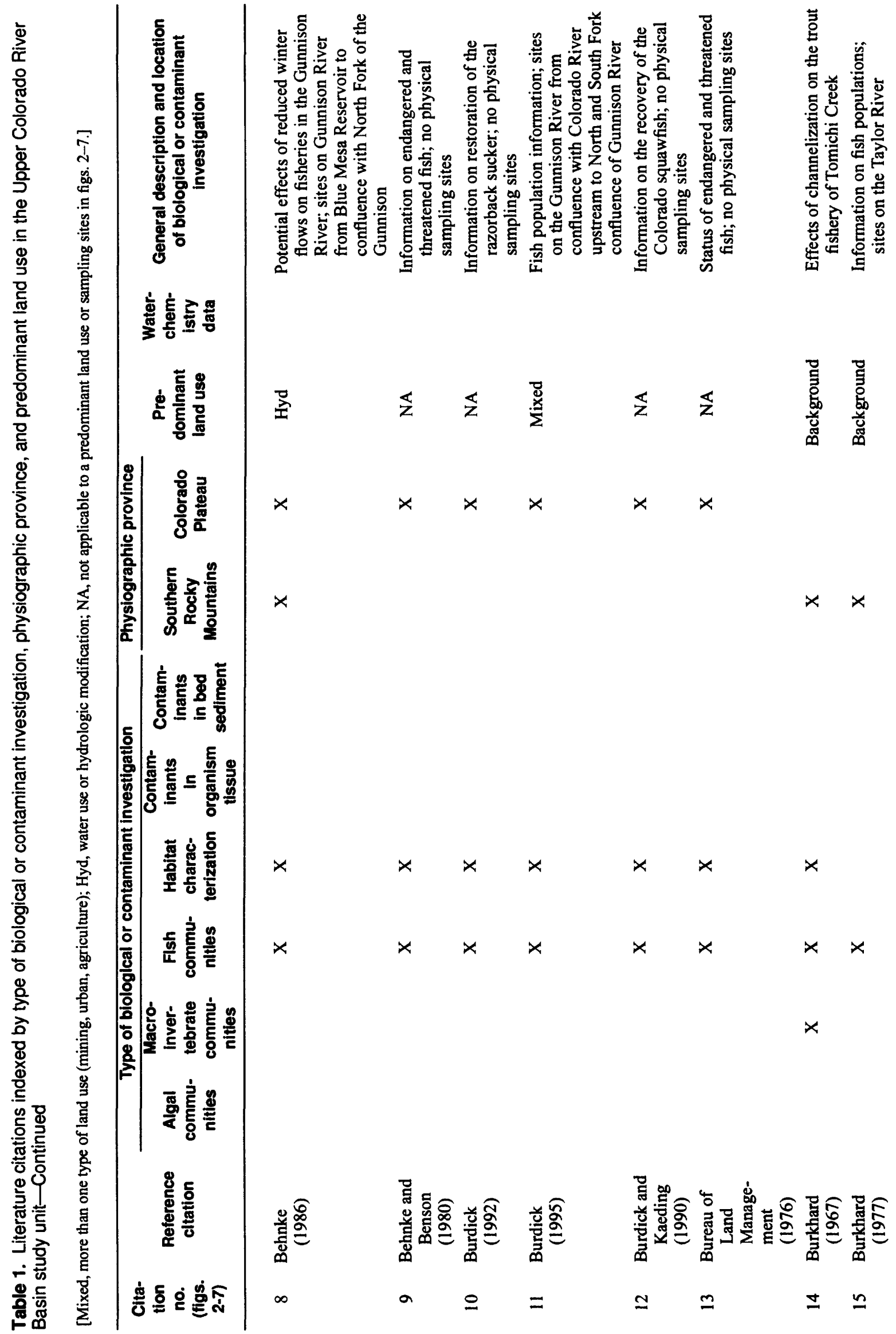

6 Summary of Blological and Contaminant Investigations Related to Stream Water Quality and Environmental Setting in the Upper 


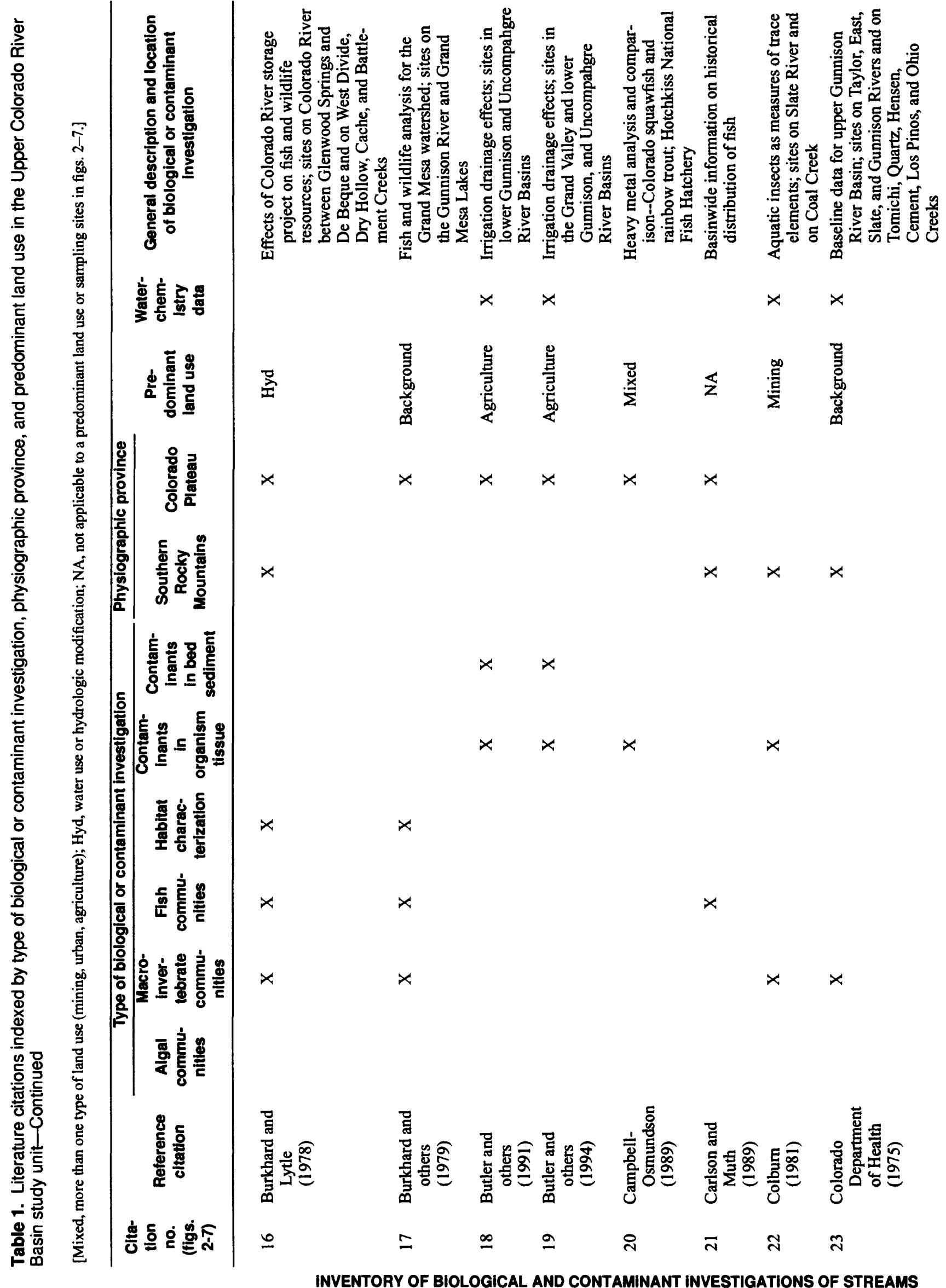




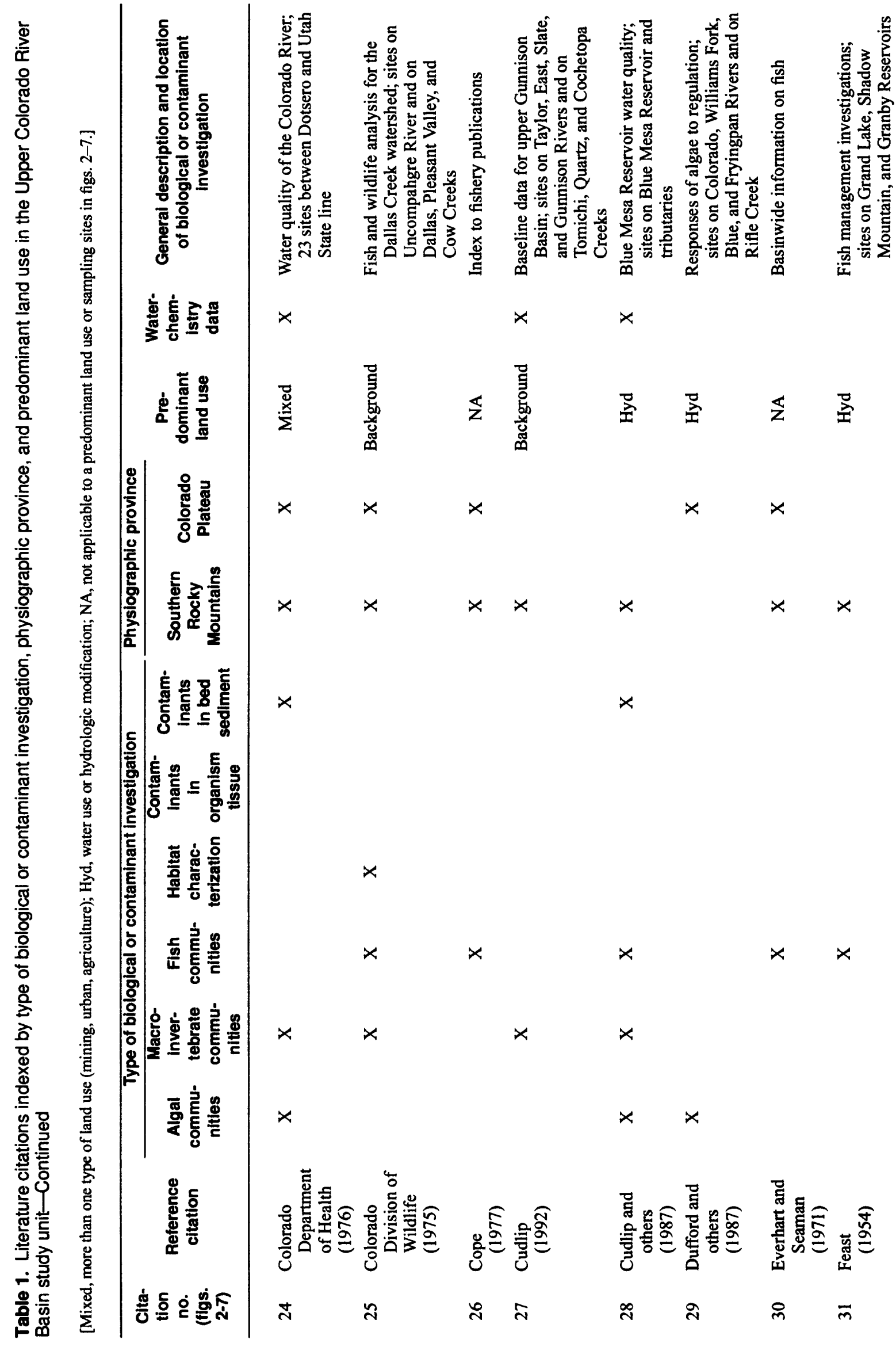

8 Summary of Biological and Contaminant investigations Related to Stream Water Quality and Environmental Setting in the Upper Colorado River Basin, 1938-95 


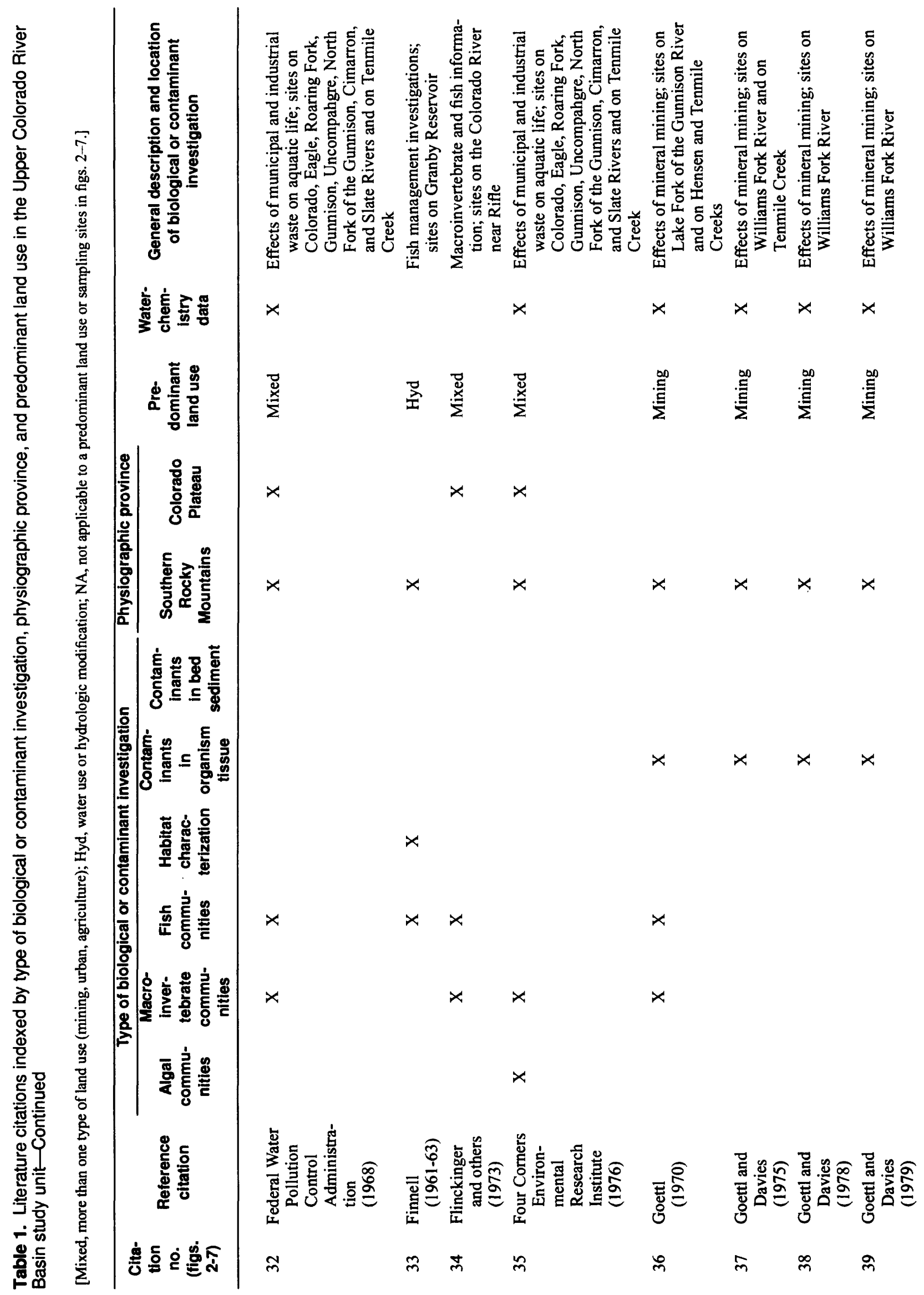




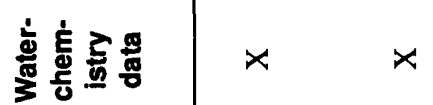

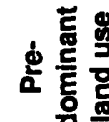

量 营

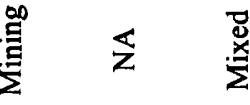

$\stackrel{\ddot{d}}{\stackrel{x}{\Sigma}}$

$\stackrel{\vec{d}}{i}$

$\stackrel{\square}{\check{x}}$

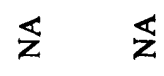

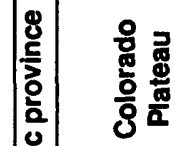

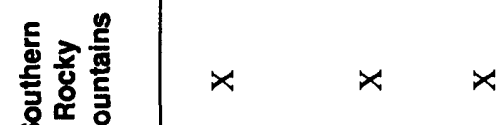

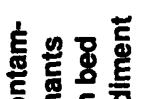

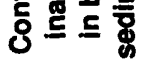

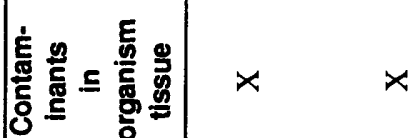

焉焉

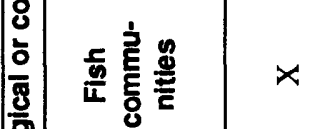

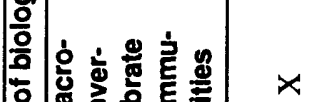

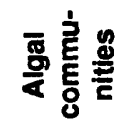

f 


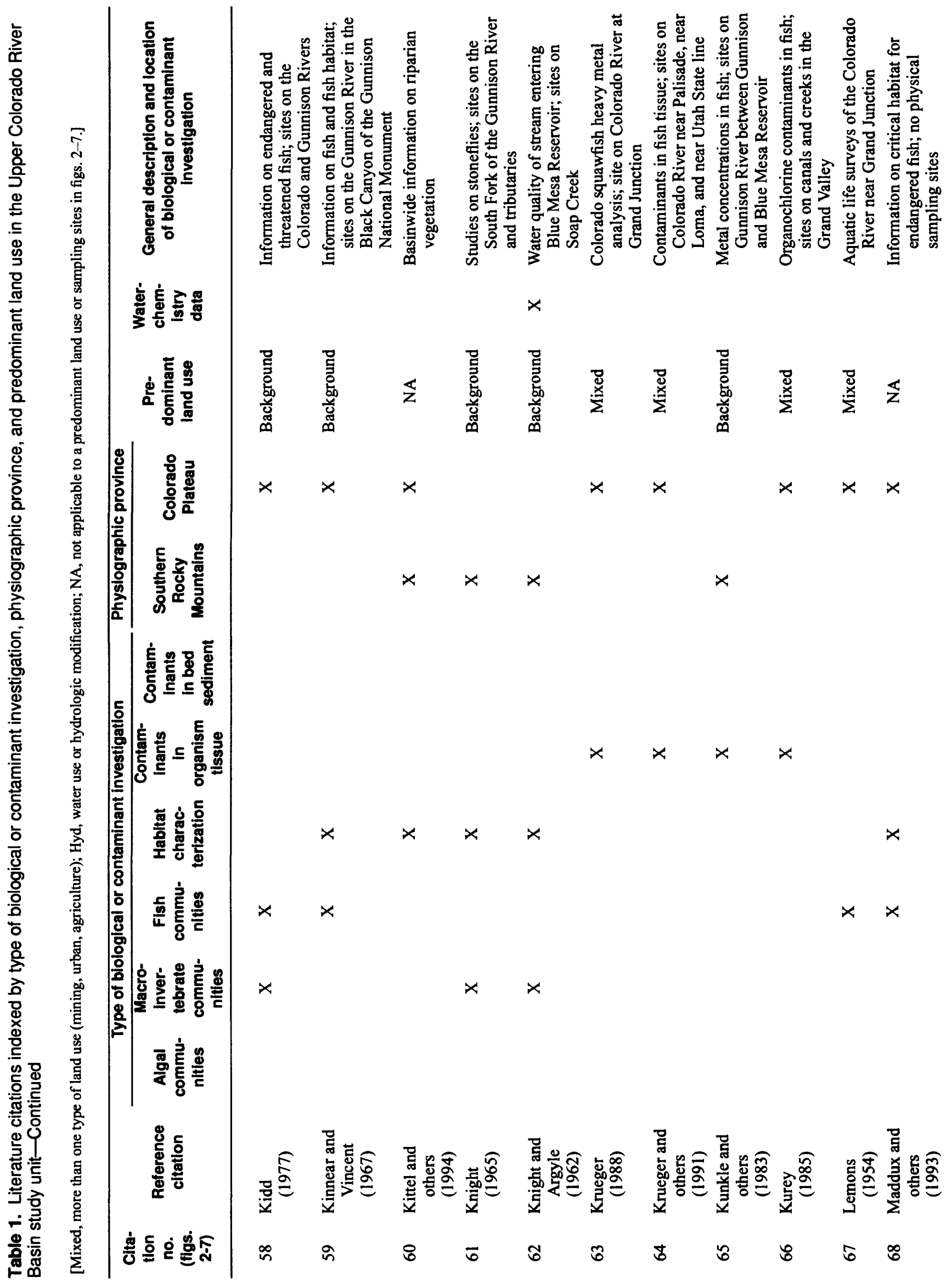




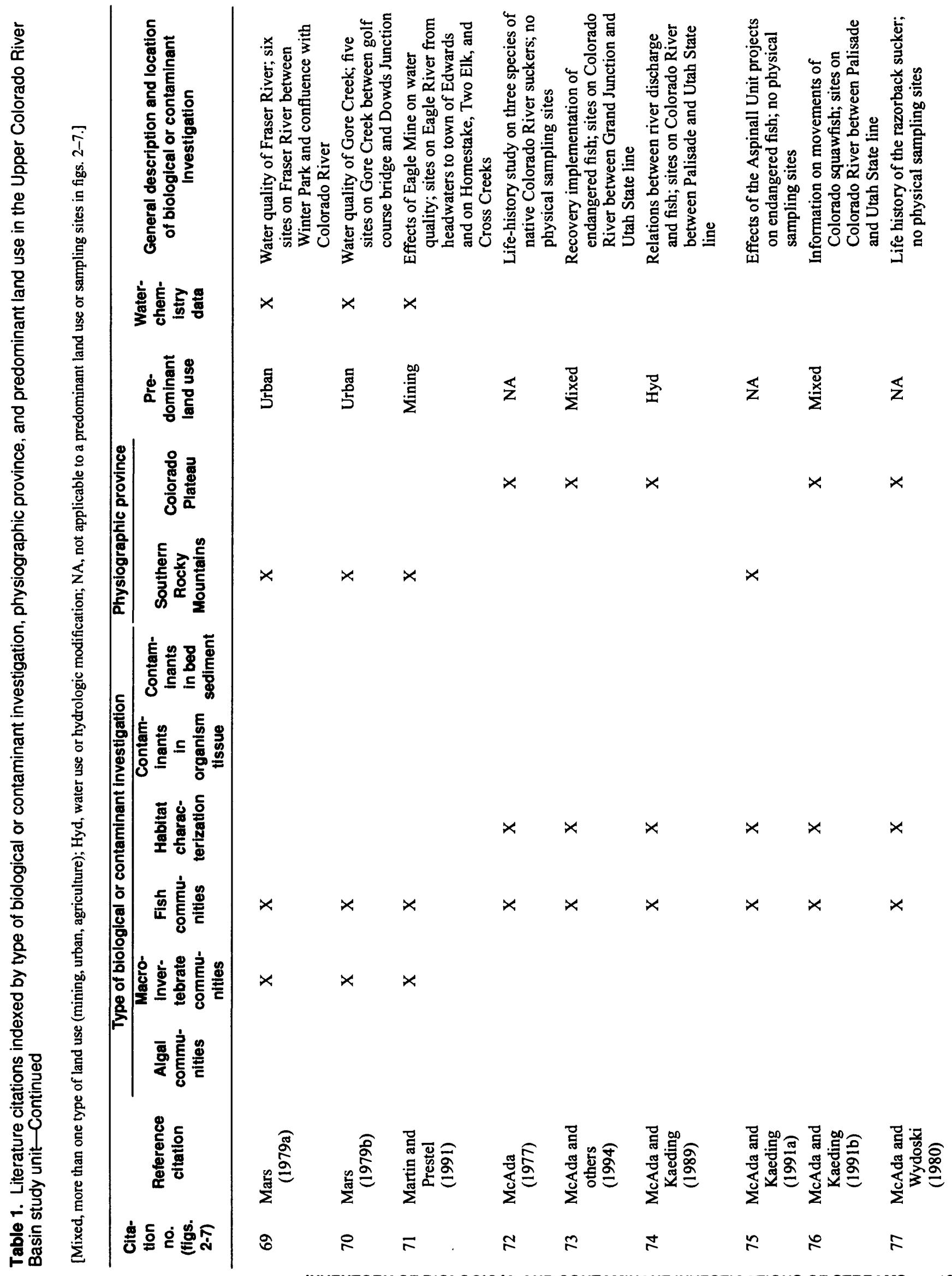




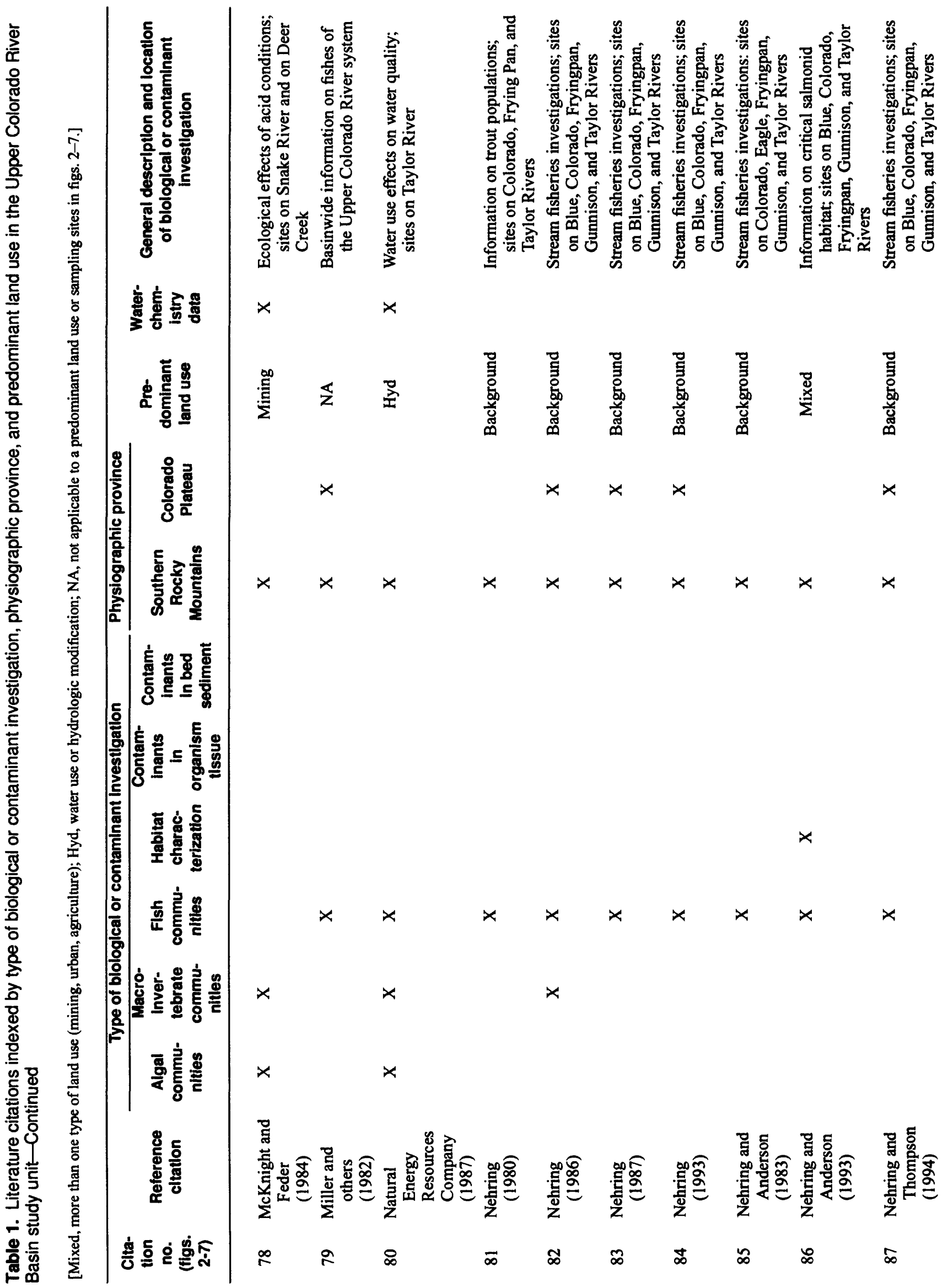

14 Summary of Blological and Contaminant Investlgatlons Related to Stream Water Quality and Envlronmental Setting In the Upper Colorado Rlver Basin, 1938-95 


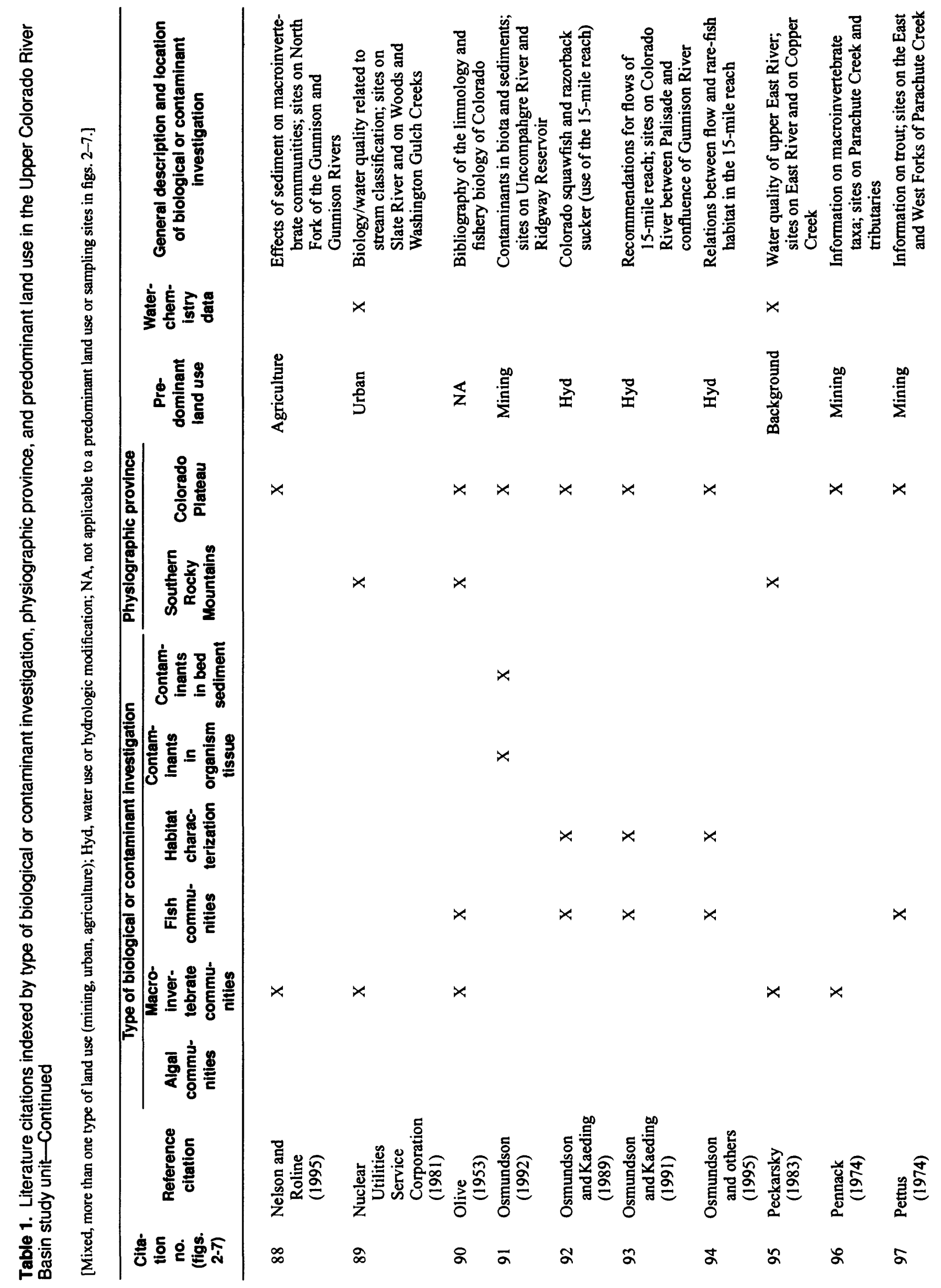




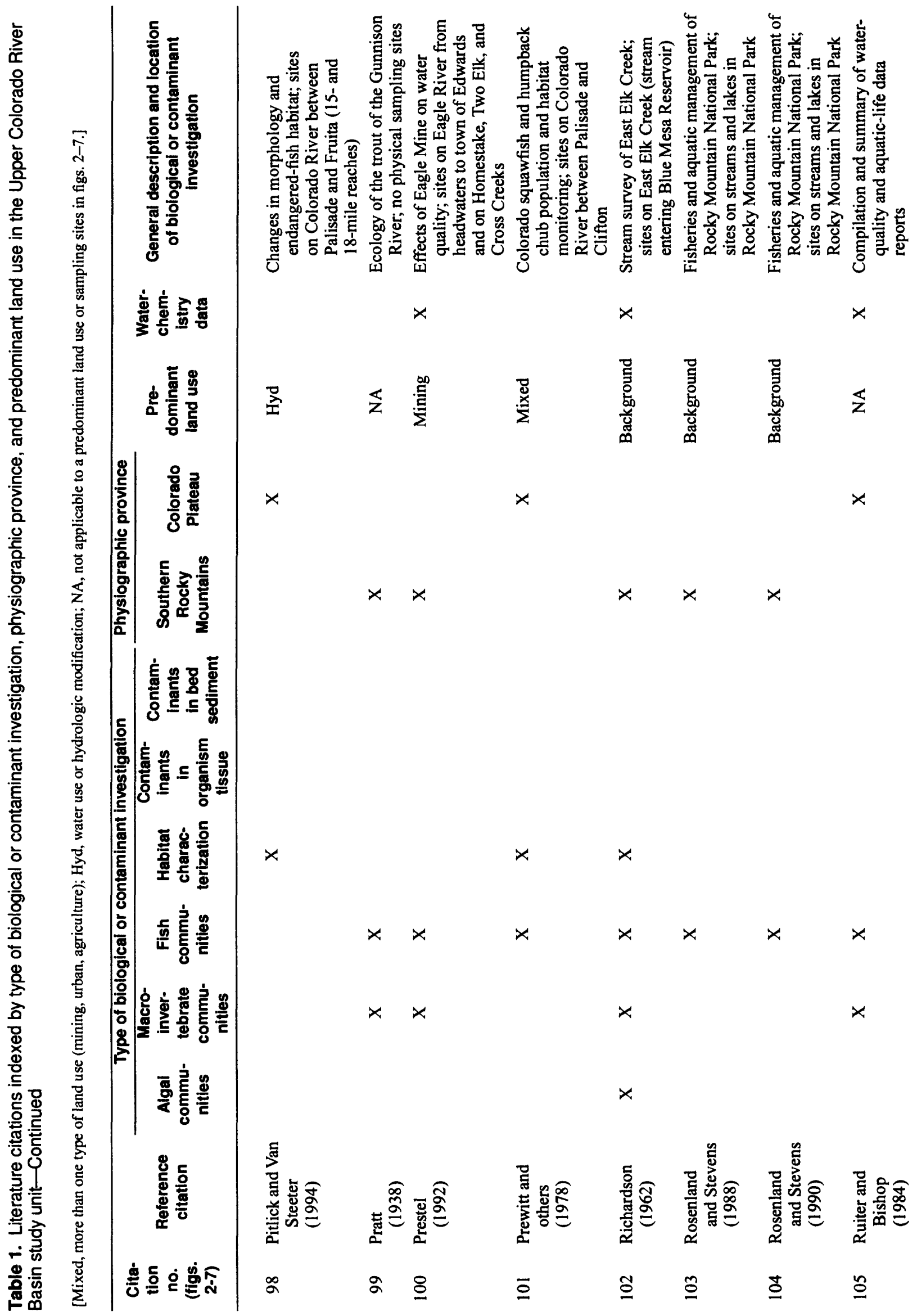

16 Summary of Biological and Contaminant Investigations Related to Stream Water Quality and Environmental Setting in the Upper 


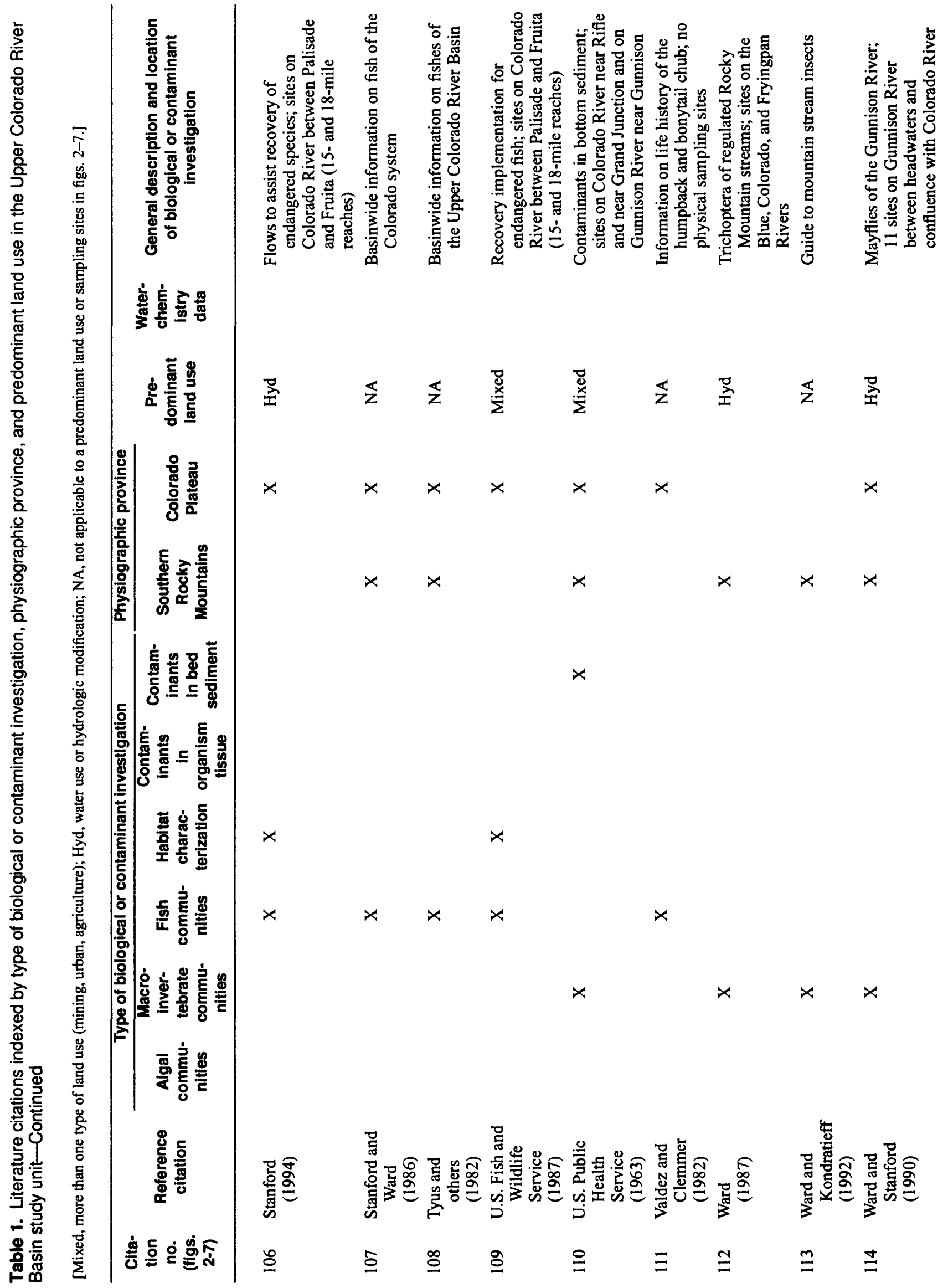




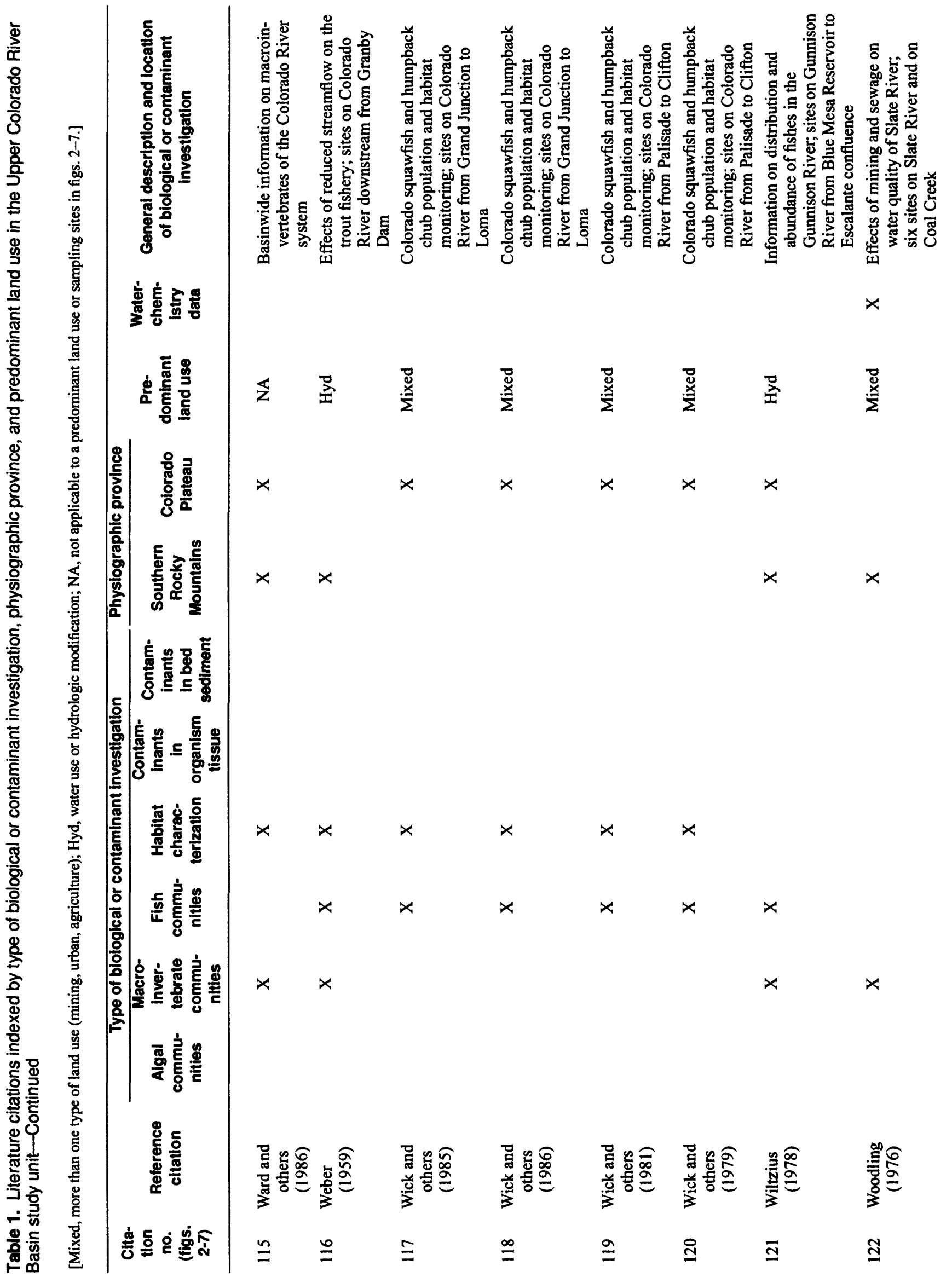

18 Summary of Biological and Contaminant investigations Related to Stream Water Quality and Environmental Setting in the Upper Colorado River Basin, 1938-95 


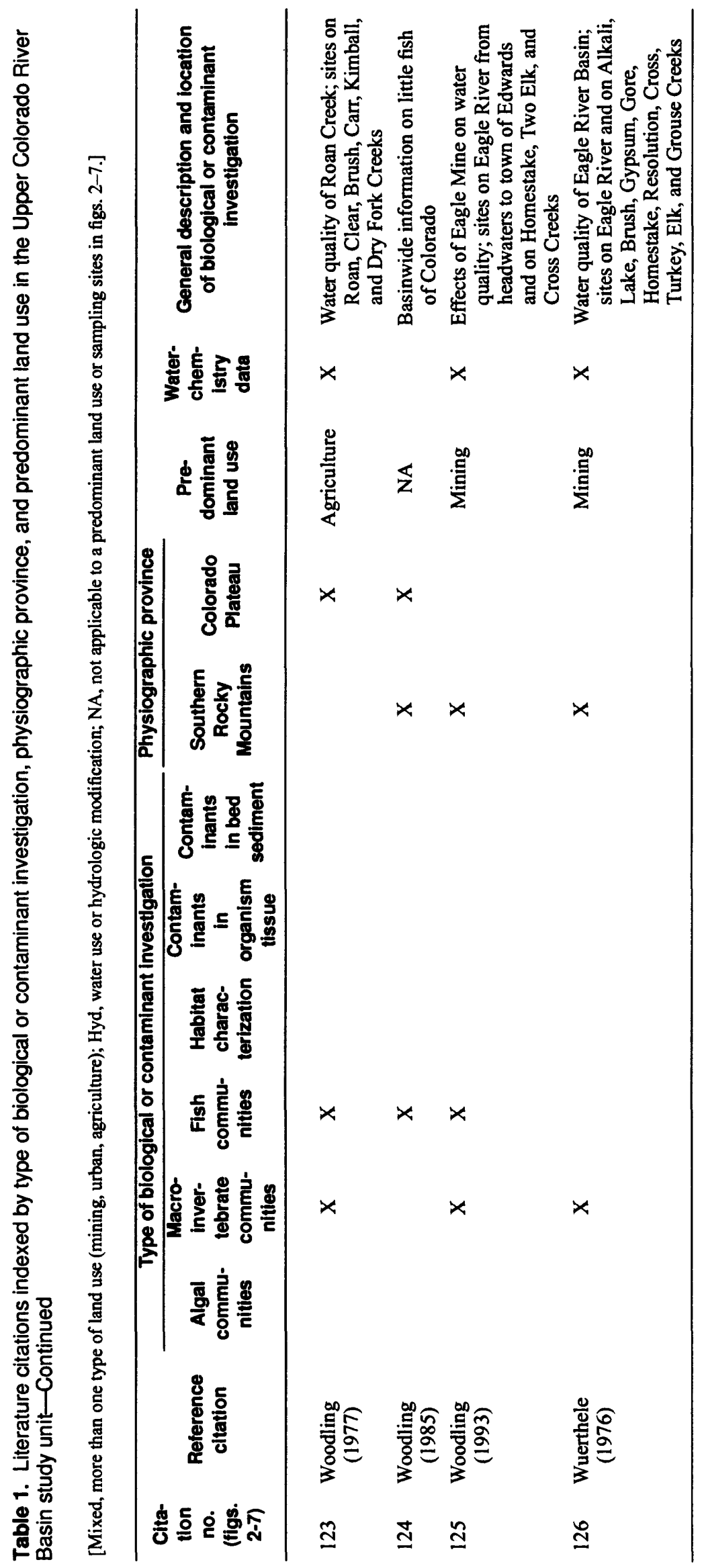


provinces and were grouped in more than one investigational category and in more than one land use.

\section{Algal Communities}

Ten investigations between 1962 and 1987 incorporated algal-community information (table 1, fig. 2). Sites in these studies were located in all predominant land-use categories and in both physiographic provinces (table 1, fig. 1). The algal data in these investigations were presented mostly as taxonomic identifications for the stream segments. The summaries of these investigations indicate that algal data are limited throughout the basin, but that algae are very useful indicators of water chemistry.

Land use can affect types, numbers, and diversity of algae. Mining areas contain different taxa than that present in agricultural areas. For instance, in the UCOL study unit, investigations done in mining areas commonly contain certain species of green algae and diatoms because of their tolerance to acidic conditions and metals. Agricultural areas commonly contain blue-green algae as the predominant species because of its tolerance to higher concentrations of nitrogen from fertilizers (Stephen Porter, U.S. Geological Survey, oral commun., 1996).

\section{Macroinvertebrate Communities}

Fifty investigations between 1938 and 1995 included macroinvertebrate-community information (table 1, fig. 3). Sites in these studies were located in a variety of land uses and in both physiographic provinces (table 1, fig. 1). These investigations presented the data as taxonomic identifications or as numbers of organisms. Some of the investigations presented both types of data. The summaries of these investigations indicate there is an abundance of information on macroinvertebrate communities throughout the UCOL study unit.

Land use can have direct effects on the composition of macroinvertebrate communities. The use of indicator species for water-quality analysis is very common in studies of macroinvertebrate communities, especially when determining the water quality from mining effects. Macroinvertebratecommunity composition can be different in mining areas than in agricultural areas. Mining areas commonly are depleted of aquatic organisms, but can contain metal-tolerant species. Agricultural areas commonly contain species, such as aquatic worms and leeches, that are tolerant of organic-carbon enrichment, sedimentation, and low dissolved-oxygen concentrations (Stephen Porter, U.S. Geological Survey, oral commun., 1996).

\section{Fish Communities}

Eighty-nine investigations summarized fish community or population information between 1938 and 1995 (table 1, fig. 4). Sites in these studies were located in a variety of land uses and in both physiographic provinces (table 1, fig. 1). The information on fish was presented as taxonomic identifications or as numbers of fish. Some of the investigations presented both types of data. The summaries of these investigations indicate that information on fish communities is extensive throughout the UCOL study unit.

Fish communities are an important issue in the UCOL study unit; the study unit contains four fishes presently listed as endangered by the U.S. Fish and Wildlife Service (USFWS) (Behnke and Benson, 1980): the Colorado squawfish (Ptychocheilus lucius), the humpback chub (Gila cypha), the bonytail chub (Gila elegans), and the razorback sucker (Xyrauchen texanus). In addition, recreational fishing in the study unit is important to many anglers.

Historically, native fauna consisted of the following minnows and suckers in addition to those fishes listed above: roundtail chub (Gila robusta), flannelmouth sucker (Catostomus latipinnis), speckled dace (Rhinichthys osculus), kendall warm springs dace (Rhinichthys osculus thermalis), and bluehead sucker (Catostomus discobolus) (Tyus and others, 1982). The current fauna of the Colorado River is dominated by exotic species. All of the big river fish that were native to the area, except for the speckled dace, flannelmouth sucker, bluehead sucker, and roundtail chub, face extinction. The cause of the disappearance of some of the native species is due to loss of habitat and competition from other species (Ward and others, 1986). Native fish in the upper reaches of the basin included mountain sucker (Catostomus platyrhynchus), mountain whitefish (Prosopium williamsoni), mottled sculpin (Cottus bairdi), and Colorado cutthroat trout (Salmo clarki pleuriticus). 


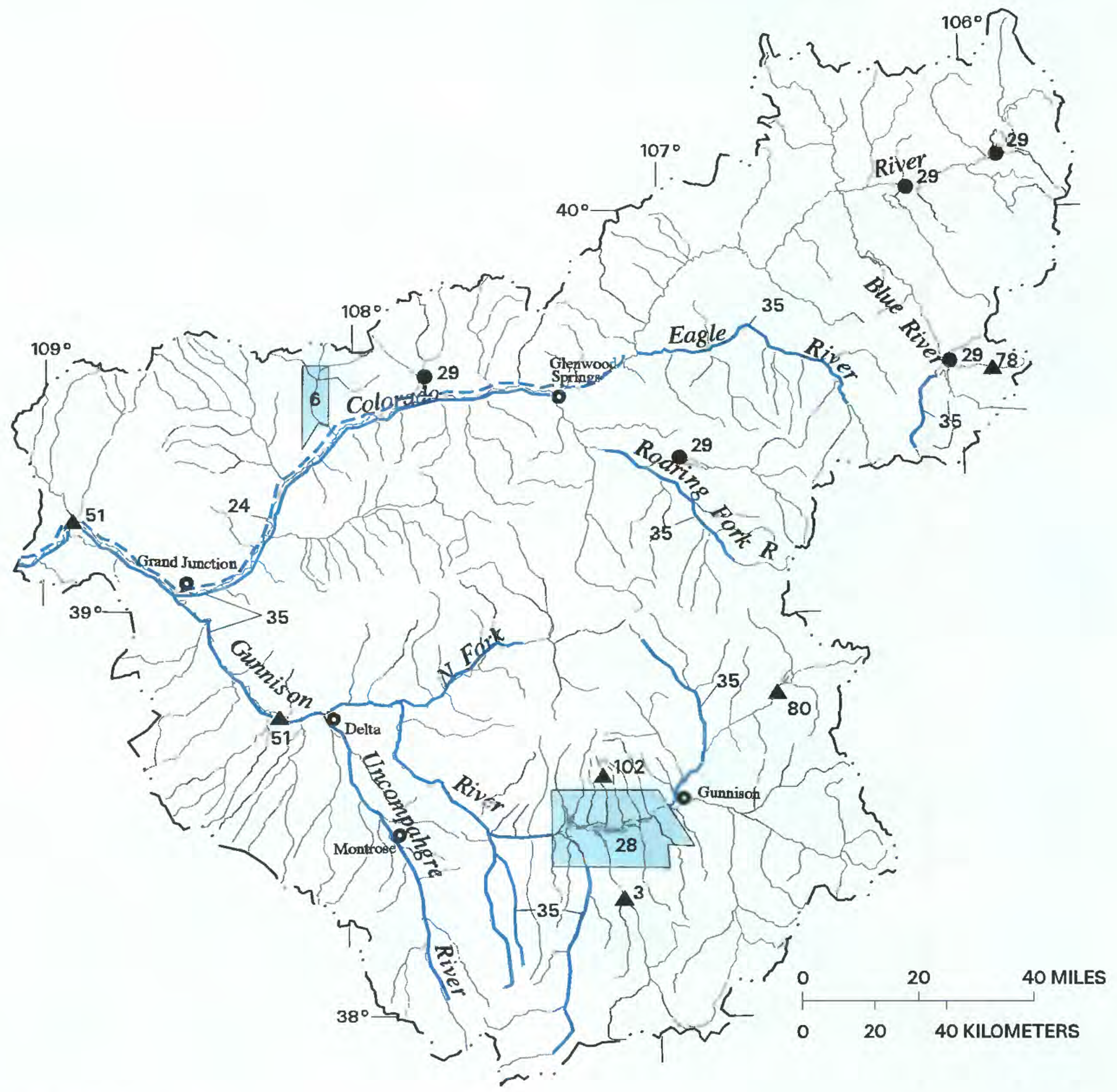

\section{EXPLANATION}

GENERAL LOCATIONS OF SITES SAMPLED FOR ALGAL-COMMUNITY INVESTIGATIONS

Number designates literature citation listed in table 1

29 SINGLE SITE SAMPLING LOCATION

$\Delta^{3}$ GENERAL SITE LOCATION Includes several or many samples collected in area

6 EXTENSIVE STUDY AREA

$\left.\frac{35}{-\underline{24}-=}\right\}$ RIVER REACH SAMPLING AREAS

Flgure 2. General locations of sites sampled for algal-community investigations. 


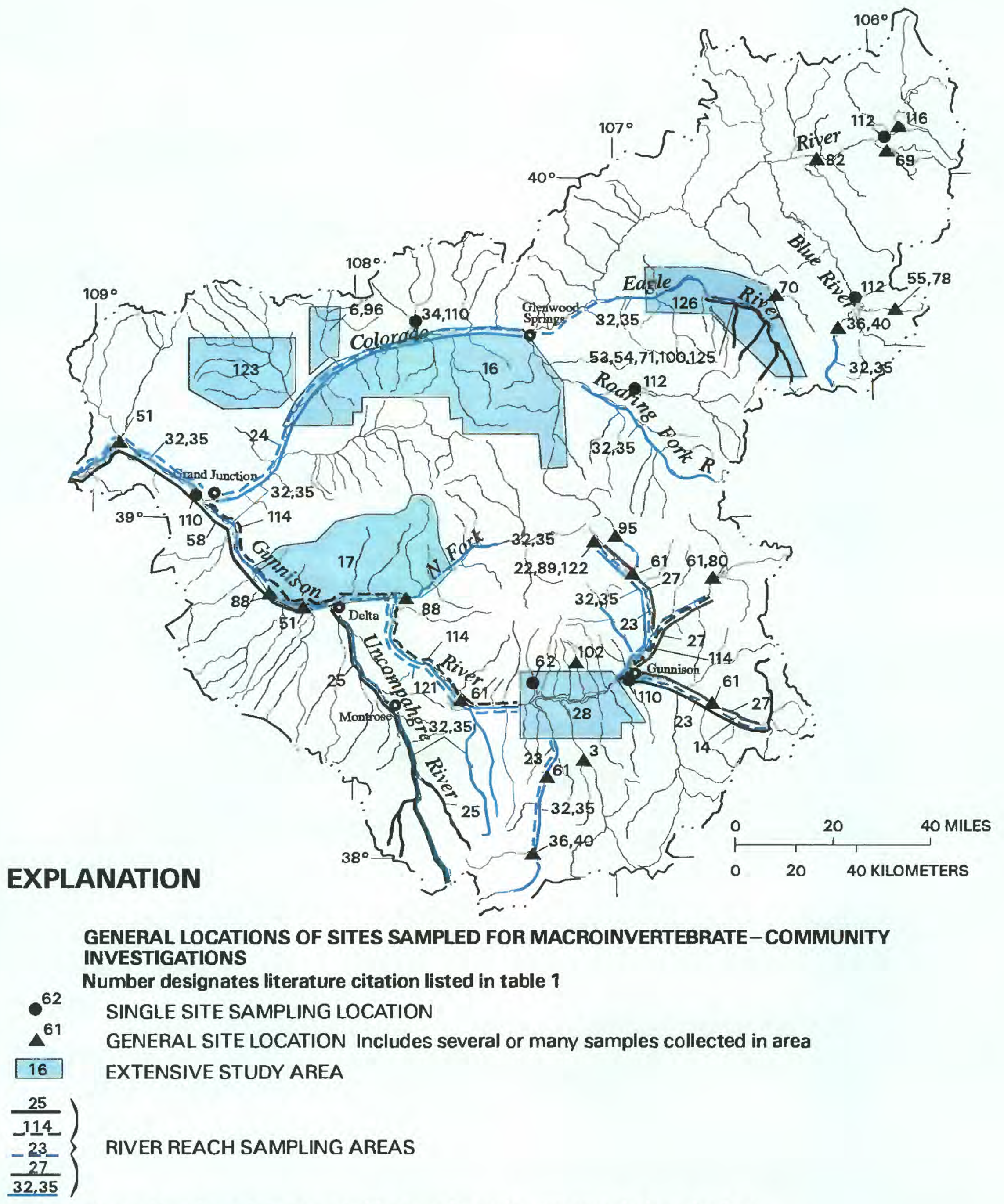

Flgure 3. General locations of sites sampled for macroinvertebrate-community investigations. 


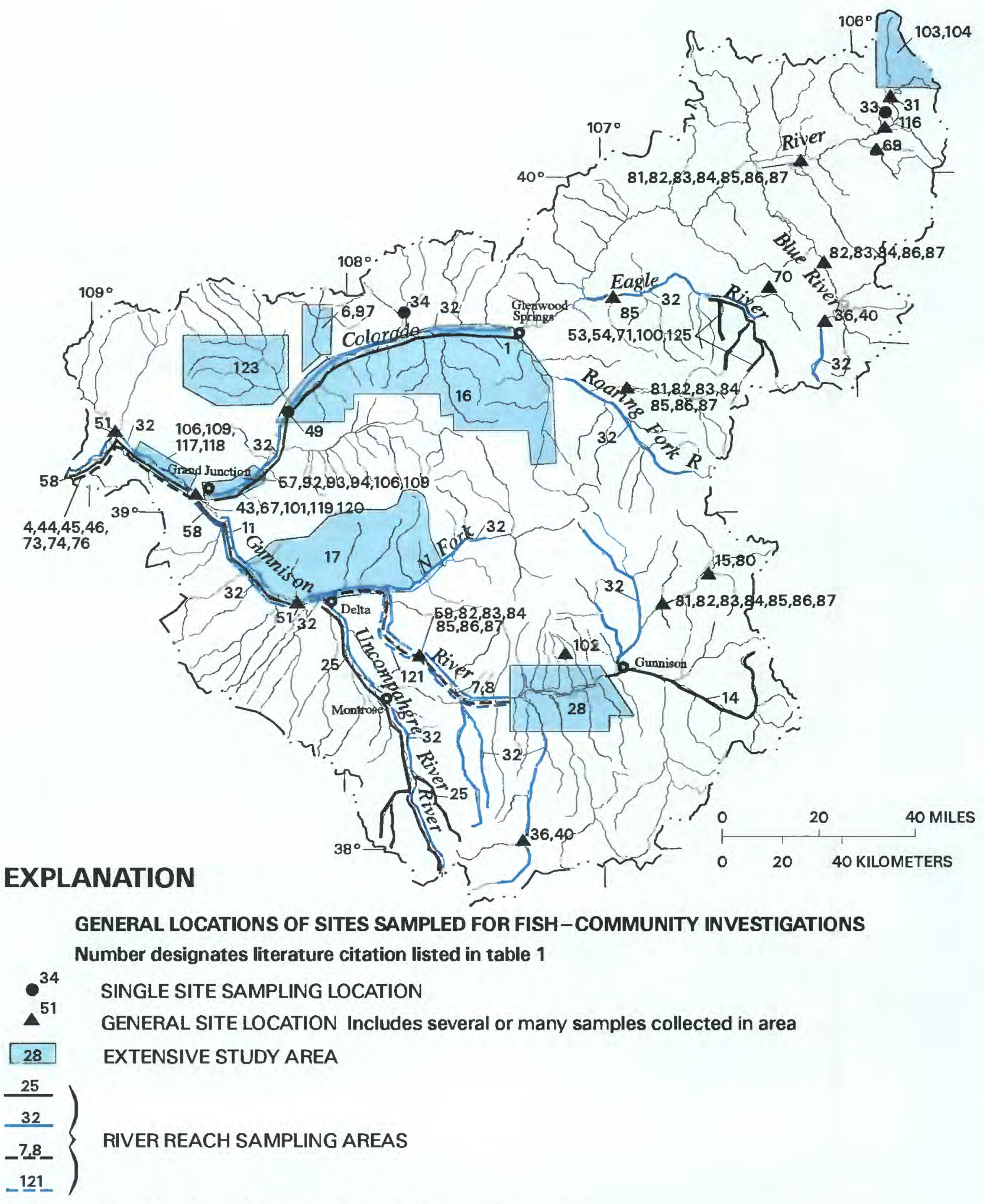

Flgure 4. General locations of sites sampled for fish-community investigations. 
Land use can have variable effects on the structure of fish communities. Intensely mined areas can be depleted of fish. Fish communities in agricultural areas most likely contain species, such as suckers, carp, and catfish, that tolerate gravel, sand, and silt substrates in slower and warmer waters. The more pristine headwater reaches and mountain streams can contain brook, brown, rainbow, and cutthroat trout.

\section{Habitat Characterization}

Fifty investigations between 1959 and 1995 included habitat-characterization information (table 1, fig. 5). Sites in these studies mostly were located in areas of hydrologic modifications and in both physiographic provinces, but primarily are limited to the Colorado Plateau (table 1, fig. 1). Habitat information from these studies mainly consisted of stream substrates, channel width, channel depth, channel morphology, and flow.

Hydrologic modifications can alter flows and degrade the necessary habitat for endangered species and fish communities. Habitat in the headwater and mountain streams is characterized by coarse substrate, such as boulders and cobbles; swift and cold water; and riparian vegetation. The lower reaches of the study unit contain fine substrates, such as gravel, sand, and silt; warm water; and less riparian vegetation.

\section{Contaminants in Organism Tissue}

Sixteen investigations between 1970 and 1994 summarized information about contaminants in tissue (table 1, fig. 6). Sites in these studies were located in a variety of land uses and in both physiographic provinces (table 1, fig. 1). Three of the studies contained information on organic and on traceelement contaminants (table 1 , citation numbers 18 , $19,64)$. One study contained information solely on organic contaminants (table 1, citation number 66). The remaining twelve studies contained information solely on trace-element contaminants. A variety of organisms, which includes aquatic plants, macroinvertebrates, fish, and other vertebrates, was used in the studies. The summaries of these investigations indicate that the watersheds for the Fraser, Blue,
Eagle, and Roaring Fork Rivers have very limited data on contaminants in tissue.

Specific contaminant constituents can be directly related to land use and geology in the UCOL study unit. Organic-contaminant investigations were most common in agricultural areas, and trace-element contaminant investigations were most common in mining areas. Investigations solely for collection of trace-element contaminant data mostly were done in the Southern Rocky Mountains physiographic province, whereas investigations for collection of both organic-contaminant and trace-element contaminant data were done in the Colorado Plateau physiographic province, especially in the Grand and Uncompahgre Valleys.

\section{Contaminants in Bed Sediment}

Seven investigations between 1963 and 1994 included information on contaminants in bed sediment (table 1, fig. 7). Sites in these studies mostly were located in agricultural and mining areas and in both physiographic provinces (table 1, fig. 1). Five of the studies contained information on organic and on traceelement contaminants (table 1 , citation numbers 3,18 , $19,24,110$ ). Two studies contained information solely on trace-element contaminants (table 1, citation numbers 28,91 ). The summaries of these investigations indicate that bed-sediment information is limited throughout the UCOL study unit.

Bed-sediment contamination can be directly related to land use and geology. Trace-element and organic contaminants often are more concentrated in bed sediments than in water. Trace-element analyses are the most common analyses done in the bedsediment investigations. The National Uranium Resource Evaluation (NURE) program has an extensive data base on selected trace elements in the UCOL study unit. Investigations done on stream reaches in the headwater areas of streams were solely trace-element investigations. The lower reaches in the valleys were investigated for trace elements and organic compounds. 


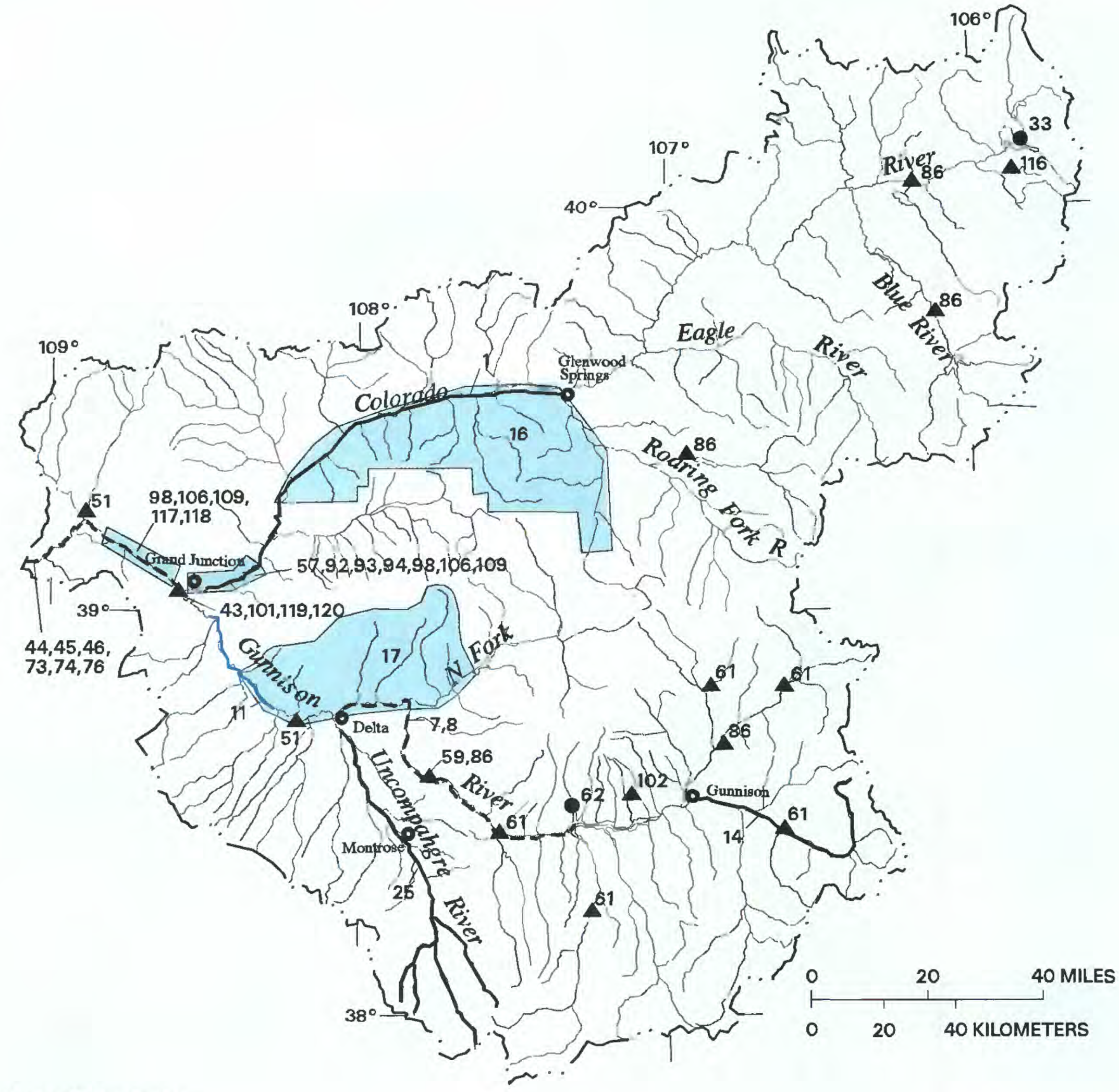

EXPLANATION

GENERAL LOCATIONS OF SITES SAMPLED FOR HABITAT-CHARACTERIZATION INVESTIGATIONS

Number designates literature citation listed in table 1

- 62 SINGLE SITE SAMPLING LOCATION

$\Delta^{61}$ GENERAL SITE LOCATION Includes several or many samples collected in area

17 EXTENSIVE STUDY AREA

$\left.\frac{25}{11} \frac{78}{-18}\right\}$

RIVER REACH SAMPLING AREAS

Flgure 5. General locations of sites sampied for habitat-characterization investigations. 


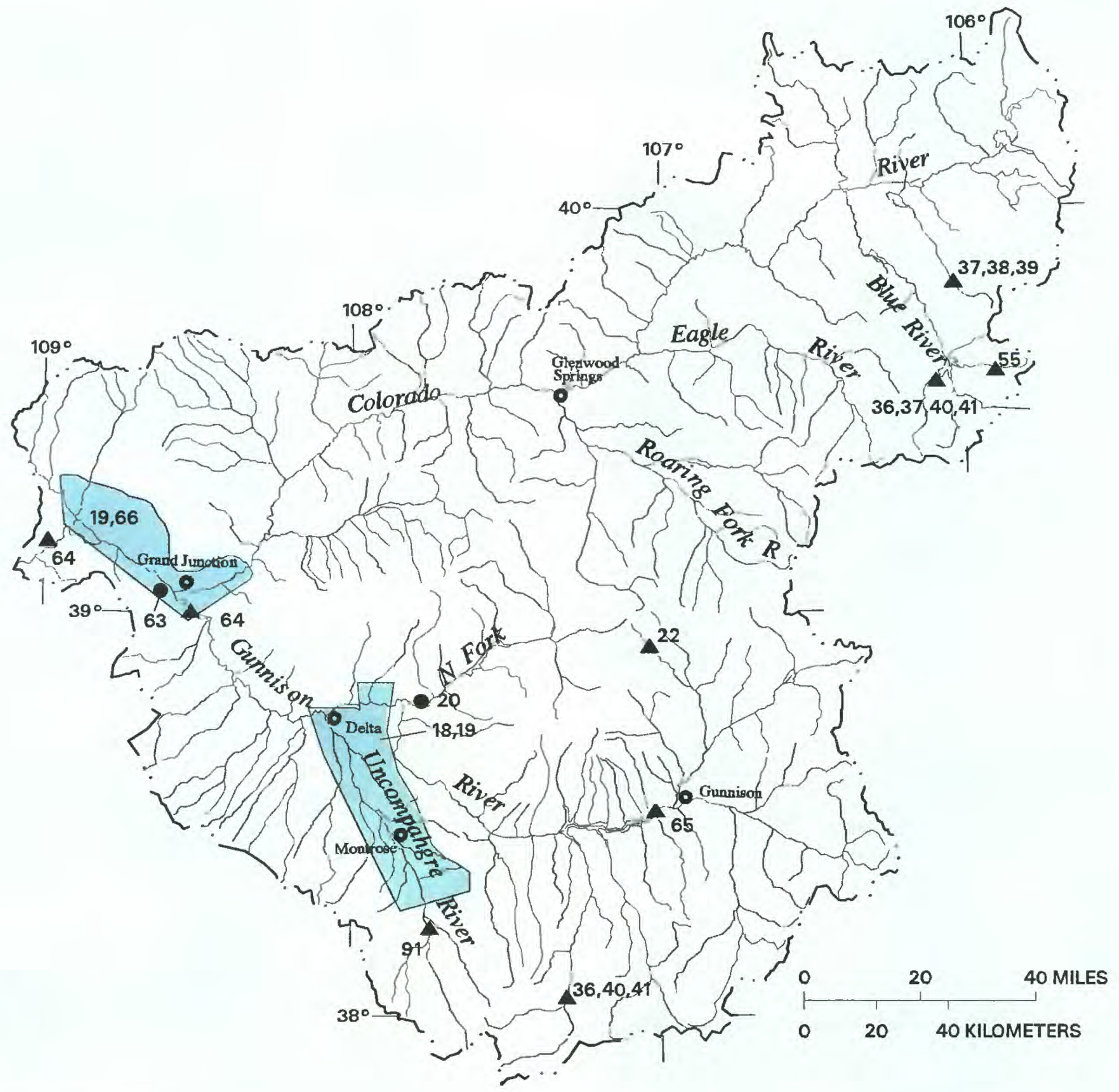

\section{EXPLANATION}

\section{GENERAL LOCATIONS OF SITES SAMPLED FOR CONTAMINANTS IN ORGANISM-TISSUE INVESTIGATIONS}

Number designates literature citation listed in table 1

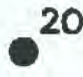

91

18,19
SINGLE SITE SAMPLING LOCATION

GENERAL SITE LOCATION Inciudes severai or many sampies coliected in area

EXTENSIVE STUDY AREA

Flgure 6. General locations of sites sampled for contaminants in organism-tissue investigations. 


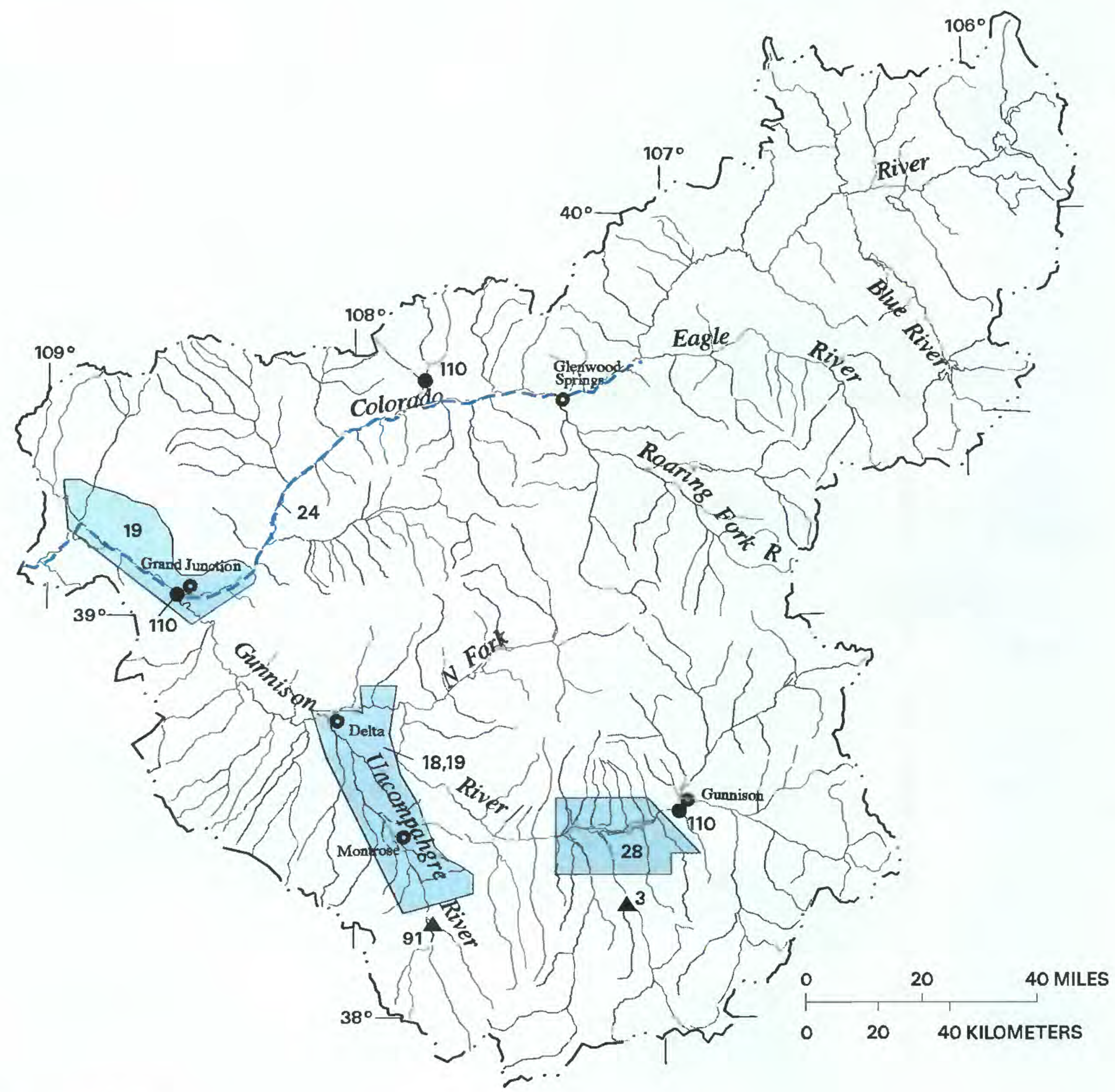

\section{EXPLANATION}

\section{GENERAL LOCATIONS OF SITES SAMPLED FOR CONTAMINANTS IN BED-SEDIMENT INVESTIGATIONS}

Number designates literature citation listed in table 1

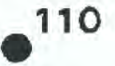

SINGLE SITE SAMPLING LOCATION

91

GENERAL SITE LOCATION Includes several or many samples collected in area

EXTENSIVE STUDY AREA

$-24$

RIVER REACH SAMPLING AREA

Figure 7. General locations of sites sampled for contaminants in bed-sediment investigations. 


\section{EFFECTS OF ENVIRONMENTAL SETTING ON BIOLOGICAL COMMUNITIES IN STREAMS}

The environmental setting of the UCOL study unit is based on natural and human factors. Natural factors that affect water-quality conditions are physiography, climate, geology, and soils. Human factors that affect water-quality conditions are mining, urbanization, agriculture, and hydrologic modifications. Apodaca and others (1996) provided a more detailed description of the environmental setting in the UCOL study unit.

\section{Natural Factors}

The UCOL study unit provides diverse habitats for aquatic biological communities. This diversity reflects the extreme ranges of altitude, climate, vegetation, and geology in the study unit. Running-water habitats vary from cool, clear, and forested headwater reaches traversing crystalline bedrock at higher altitudes, to warm, sluggish, and saline reaches at lower altitudes that have low gradients and fine substrates.

Algae, macroinvertebrates, and fish present in the Southern Rocky Mountains and the Colorado Plateau physiographic provinces vary with altitude and physical habitat (table 2). The major controlling

Table 2. Major aquatic biological taxa in the Southern Rocky Mountains and Colorado Plateau physiographic provinces of the Upper Colorado River Basin study unit

\begin{tabular}{|c|c|c|}
\hline Taxonomic group & Southern Rocky Mountains & Colorado Plateau \\
\hline \multirow[t]{4}{*}{ Algae $^{l}$} & Chlorophyta (green algae) & Chlorophyta \\
\hline & $\begin{array}{l}\text { Chrysophyta } \\
\text { Bacillariophyceae (diatoms) } \\
\text { Chrysophyceae (golden-brown algae) }\end{array}$ & $\begin{array}{l}\text { Chrysophyta } \\
\text { Bacillariophyceae } \\
\text { Chrysophyceae }\end{array}$ \\
\hline & Cyanophyta (blue-green algae) & Cyanophyta \\
\hline & Pyrrhophyta (dinoflagellates) & Euglenophyta (euglenoid algae) \\
\hline \multirow[t]{11}{*}{ Macroinvertebrates ${ }^{2}$} & Ephemeroptera (mayflies) & Ephemeroptera \\
\hline & Trichoptera (caddisflies) & Trichoptera \\
\hline & Diptera (true flies) & Diptera \\
\hline & Coleoptera (beetles) & Coleoptera \\
\hline & Odonata (dragonflies and damselflies) & Odonata \\
\hline & Plecoptera (stoneflies) & Megaloptera (aiderflies and dobsonflies) \\
\hline & Amphipoda (scuds) & Amphipoda \\
\hline & Oligochaeta (worms) & Oligochaeta \\
\hline & Tricladida (flatworms) & Decapoda (crayfish) \\
\hline & Nematoda (roundworms) & Gastropoda (snails) \\
\hline & Gastropoda & Hirudinea (leeches) \\
\hline \multirow[t]{9}{*}{ Fish $^{3}$} & Salmonidae (salmon and trout) & Salmonidae \\
\hline & Cyprinidae (minnows and carp) & Cyprinidae \\
\hline & Catostomidae (suckers) & Catostomidae \\
\hline & Percidae (perches) & Percidae \\
\hline & Cottidae (sculpins) & Cottidae \\
\hline & Esocidae (northern pike) & Ictaluridae (catfish) \\
\hline & & Cyprinodontidae (topminnows and killifish) \\
\hline & & Poeciliidae (mosquitofish) \\
\hline & & Centrarchidae (bass and sunfish) \\
\hline
\end{tabular}

\footnotetext{
'Colorado Department of Health (1976); Apley (1982); Natural Energy Resources Company (1987).

${ }^{2}$ Federal Water Pollution Control Administration (1968); Ward and others (1986); Ward and Kondratieff (1992).

${ }^{3}$ Everhart and Seaman (1971); Woodling (1985).
} 
factors that determine composition of biological communities are changes in water temperature, water discharge and velocity, substrate and suspended material, chemical conditions, and aquatic and riparian vegetation (Ward and Kondratieff, 1992). The differences in biological communities between the Southern Rocky Mountains and the Colorado Plateau are the result of a combination of these factors. The Southern Rocky Mountains physiographic province contains streams that have steep gradients, cobble and boulder substrates, and extended periods of ice and snow cover. The Colorado Plateau physiographic province contains the larger reaches of the Colorado River that are characterized by sand and silt substrates, warmer water, sparse vegetation, and lower gradients. Distinct biological communities are associated with the two physiographic provinces; however, overlap of species can occur in the transition zone, which is located along the division line of the two physiographic provinces. The predominant algae in the Southern Rocky Mountains are green algae and diatoms. The predominant algae in the Colorado Plateau are blue-green, golden-brown, and green algae. In the higher altitudes, caddisflies, mayflies, and stoneflies are the predominant macroinvertebrates. In the transition zone from high-altitude to low-altitude streams, caddisflies and mayflies become less predominant; stoneflies are rare; and crayfish, dobsonflies, and damselflies are more common. The lower altitudes are favorable to species, such as aquatic worms, leeches, and dragonflies. In fish communities, cold-water species, such as trout, predominate in the higher altitudes, and warm water species, such as carp, catfish, and suckers, predominate in the lower altitudes (table 2). The information in table 2 is a general summary of the major biological taxa in the physiographic provinces and does not represent all species in the UCOL study unit.

\section{Human Factors}

Human factors can adversely affect water quality, biota, and habitat as a result of point and nonpoint sources of chemical and physical constituents. Mining, urbanization, agriculture, and hydrologic modifications are the principal activities that affect water quality and available habitat in the UCOL study unit (Driver, 1994).
The environmental setting of the Southern Rocky Mountains physiographic province consists primarily of mining, urban, and recreational land uses. In many of the headwater reaches of the Colorado River and its tributaries, mining activities have severely affected aquatic life and habitat. As tributaries converge, precipitation of metals occurs as a result of dilution, which also results in direct effects on the fauna and habitat by coating the substrates of streams with toxic constituents. The Colorado Division of Wildlife has made biological assessments of the Eagle River Superfund Site and has evaluated the effects of mining on the water quality and biota of the Eagle River. These studies (table 1, citation numbers 53, 54, 71, 100, and 125) are good examples of how mining causes decreased numbers of organisms and affects community structures of macroinvertebrate and fish populations. Mining areas can be depleted of organisms or contain a low diversity of species; however, acid-tolerant algae, such as species of green algae and diatoms, and metaltolerant caddisflies can be present in areas affected by mining (Stephen Porter, U.S. Geological Survey, oral commun., 1996).

Urbanization, recreation, and their associated effects on biological communities are important waterquality issues in the UCOL study unit. Development and construction of homes can affect water quality by increasing sedimentation that can affect macroinvertebrate life cycles and fish reproduction. Septic systems are the predominant method of sewage waste disposal for areas that are located outside sanitation districts and municipal treatment facilities of major towns and cities. Increasing development of these septic systems increases nutrient loading, which then affects the biological community. The Colorado Department of Health conducted water-quality investigations (table 1 , citation numbers 69 and 70) of the Fraser River and Gore Creek watersheds, which are typical examples of areas affected by urbanization and recreation in the study unit. These studies indicate an increase in nutrients and changes in macroinvertebrate communities as the streams flow through the urbanized areas. Most roads and highways within the UCOL study unit are developed and located next to streams. Increasing urbanization and recreation have resulted in increased use and size of these roads. Sanding and salting of and stormwater runoff from these highways can adversely 
affect water quality and associated biological communities.

The environmental setting of the Colorado Plateau physiographic province primarily consists of agriculture and urban land uses. Nutrients from fertilization carried from an agricultural site to a water body can cause detrimental effects on various species of flora and fauna. Different algal species are affected by changes in habitat and by availability of nutrients. Pesticides commonly used during agricultural activities can be transported to streams and can have damaging effects on the biota. Agricultural areas might contain species, such as blue-green algae, aquatic worms, and suckers, that tolerate organic enrichment, sedimentation, and lower dissolvedoxygen concentrations. The USGS and USFWS conducted investigations in the Grand Valley and in the lower Gunnison and Uncompahgre River Basins (table 1, citation numbers 18 and 19) that provided valuable information on the potential effects of irrigation return flows on water quality and biota. Results indicated that the degradation of the irrigation return flows can alter the biological communities by eliminating algae and invertebrates necessary for the aquatic food chain. Grazing is a predominant land use in the study unit, and the movement of cattle to and from water can adversely affect the riparian vegetation and can eliminate the undercut banks and aquatic and terrestrial vegetation.

One of the most important factors that affects the biological communities and ecology of the Upper Colorado River system is the extent of hydrologic modifications. Most segments of the Colorado River and its tributaries have become a series of reservoirs with tailwaters between them. Except for the remote headwaters, almost all running water in the UCOL study unit is affected by regulation (Stanford and Ward, 1986). The USFWS has evaluated the effects of flow regimes on fish habitats and populations (primarily endangered species) in several studies (table 1, citation numbers 57, 93, 106, and 109). Reservoirs essentially halt the migration of fish, but more importantly, dams and interbasin water transfers change the flow regime of streams, the temperature of the water, and the habitat of the fish community. These hydrologic modifications affect functional, chemical, and physical characteristics of the water that enters the reservoir, and these changes can alter the life cycles, diversity, types, and numbers of organisms in biological communities. Flow regimes of streams shape the gross physical structure of the streams, such as channel morphology and substrate type; this structure, in turn, determines the quantity and quality of various habitats available for fish (Osmundson and Kaeding, 1991).

\section{SUMMARY}

The U.S. Geological Survey's National WaterQuality Assessment (NAWQA) program is a longterm, interdisciplinary program that is designed to integrate chemical, physical, and biological data to assess the Nation's ground-water and surface-water quality. The Upper Colorado River Basin (UCOL) study unit is one of 60 study units established to assess current water-quality conditions, define long-term trends, and identify major natural and human factors affecting water-quality conditions throughout the Nation. This report summarizes historical data that can be used to design biological sampling strategies to fill in gaps in the biological and contaminant data and to effectively address critical water-quality issues in the UCOL study unit.

One-hundred-twenty-six references concerning the ecology of aquatic organisms and contaminants were compiled from computerized literature searches of biological data bases and by contacting other Federal, State, and local agencies. Biological and contaminant investigations that have been conducted throughout the basin since 1938 were categorized according to four general categories of biological investigations and two categories of contaminant investigations: algal communities, macroinvertebrate communities, fish communities, habitat characterization, contaminants in organism tissue, and contaminants in bed sediment. The studies were identified by their locations in two physiographic provinces, the Southern Rocky Mountains and the Colorado Plateau, and by the predominant land use in the area of the investigation.

Studies on algae and contaminants in organism tissue and in bed sediment are very limited throughout the basin. Studies on macroinvertebrate and fish communities and habitat characterization are the most abundant.

Distinct biological communities are associated with the two physiographic provinces in the UCOL study unit. Natural and human factors can affect biological communities and their composition. 
Natural factors that affect background water-quality conditions are physiography, climate, geology, and soils. Different algal species are affected by changes in habitat and by the availability of nutrients. The predominant algae in the high-altitude streams are green algae and diatoms. In the lower altitudes, bluegreen, golden-brown, and green algae are predominant. Macroinvertebrate communities vary by altitude, substrate, water temperature, and concentration of dissolved oxygen. Mayflies, caddisflies, and stoneflies compose most of the species present in the high-altitude streams. In the transition zone from high-altitude to low-altitude streams, caddisflies and mayflies become less predominant; stoneflies are rare; and crayfish, dobsonflies, and damselflies are more common. Because of changes in the physical environment at lower altitudes, additional species, such as aquatic worms, leeches, and dragonflies, also are present.

Human factors that affect water-quality conditions are mining, urbanization, agriculture, and hydrologic modifications. Land uses affect biological communities and their composition. Mining areas can be depleted of organisms or contain a low diversity of species; however, acid-tolerant algae, such as green algae and diatoms, and metal-tolerant caddisflies can be present in areas affected by mining. Urbanized areas are located in the Southern Rocky Mountains and in the Colorado Plateau and contain species characteristic of the physiographic province. Agricultural areas contain species, such as blue-green algae, aquatic worms, and suckers and carp, that can tolerate organic enrichment, sedimentation, and lower concentrations of dissolved oxygen.

The sampling design for the biological component in the UCOL study unit can be enhanced with this summary of biological and contaminant information. The NAWQA program attempts to fill in some of the gaps in biological data. This historical biological summary can be used to select ecological sites, design sampling strategies, and integrate physical, chemical, and biological information for the UCOL study unit.

\section{REFERENCES CITED}

Anderson, Richard, 1994, Endangered fishes: Fort Collins, Colorado Division of Wildlife, Federal Aid Project SE319, Job Progress Report, 29 p., plus appendix.
Andrews, A.K., 1970, The distribution and life history of the fathead minnow (Pimephales promelsa Rafinesque) in Colorado: Fort Collins, Colo., Ph.D. dissertation, $141 \mathrm{p}$.

Apley, M.L., 1982, Powderhorn surface water quality study, 1979-1981: Gunnison, Colo., Western State College, $75 \mathrm{p}$.

Apodaca, L.E., Driver, N.E., Stephens, V.C., and Spahr, N.E, 1996, Environmental setting and implications on water quality, Upper Colorado River Basin, Colorado and Utah: U.S. Geological Survey WaterResources Investigations Report 95-4263, 34 p.

Archer, D.L., Kaeding, L.R., Burdick, B.D., and McAda, C.W., 1985, A study of the endangered fishes of the Upper Colorado River: U.S. Fish and Wildlife Service Final Report 14-16-0006-82-959, 134 p.

Bauch, N.J., and Apodaca, L.E., 1995, Bibliography, indices, and data sources of water-related studies, Upper Colorado River Basin, Colorado and Utah, 1872-1995: U.S. Geological Survey Open-File Report 95-450, 282 p.

Bauman, R.W., Gaufin, A.R., and Surdick, R.F., 1977, The stoneflies (Plecoptera) of the Rocky Mountains: American Entomological Society Memoirs, v. 31, p. 1-208.

Bechtel Corporation and Ecology Consultants, Inc., 1975, Environmental baseline program 1974-1975-Oil shale prototype development, Parachute Creek: Parachute, Colo., Union Oil Company of California, $293 \mathrm{p}$.

Behnke, R.J., 1985, Fisheries impact analysis for yearround flow depletion of $1000 \mathrm{cfs}$ from Gunnison River in Black Canyon area: Fort Collins, Colorado State University, $23 \mathrm{p}$.

Behnke, R.J., 1986, Potential impacts of reduced winter flows in Gunnison River on trout reproduction and growth in relation to lower temperatures and ice formation: Fort Collins, Colorado State University, 10 p.

Behnke, R.J., and Benson, D.E., 1980, Endangered and threatened fishes of the Upper Colorado River Basin: Fort Collins, Colorado State University Cooperative Extension Service Bulletin 503A, 34 p.

Burdick, B.D., 1992, A plan to evaluate stocking to augment or restore razorback sucker in the Upper Colorado River, final report: Grand Junction, Colo., U.S. Fish and Wildlife Service Colorado River Fishery Project, $56 \mathrm{p}$.

Burdick, B.D., 1995, Ichthyofaunal studies of the Gunnison River, Colorado, 1992-1994: Grand Junction, Colo., U.S. Fish and Wildlife Service Recovery Implementation Program for the endangered fishes of the Upper Colorado River Basin, 60 p., plus appendix. 
Burdick, B.D., and Kaeding, L.R., 1990, Biological merits of fish passage as part of recovery of Colorado squawfish in the Upper Colorado River Basin, final report: Grand Junction, Colo., U.S. Fish and Wildlife Service Colorado River Fishery Project, $23 \mathrm{p}$.

Bureau of Land Management, 1976, Status of endangered and threatened fish species in Colorado: Bureau of Land Management Technical Note 280, 23 p.

Burkhard, W.T., 1967, Stream fishery studies-Effects of channelization on the trout fishery of Tomichi Creek: Denver, Colorado Department of Game, Fish, and Parks, Federal Aid Project F-026-R-04, Job 6, 9 p.

Burkhard, W.T., 1977, Taylor River flow investigations: Denver, Colorado Division of Wildlife, Federal Aid Project F-51-R-4, Job Interim Report, Job 1, 49 p.

Burkhard, W.T., and Lytle, T.A., 1978, Final report for fish and wildlife resources analysis of the West Divide Project: Grand Junction, Colorado Division of Wildlife, $310 \mathrm{p}$.

Burkhard, W.T., Smith, N.F., Lytle, T.A., and Burdick, H.E., 1979, Final report for fish and wildlife resource analysis of the Grand Mesa Project: Grand Junction, Colorado Division of Wildlife, $515 \mathrm{p}$.

Butler, D.L., Krueger, R.P., Campbell-Osmundson, Barbara, Thompson, A.L., and McCall, S.K., 1991, Reconnaissance investigation of water quality, bottom sediment, and biota associated with irrigation drainage in the Gunnison and Uncompahgre River Basins and at Sweitzer Lake, west-central Colorado, 1988-89: U.S. Geological Survey Water-Resources Investigations Report 91-4103, 99 p.

Butler, D.L., Wright, W.G., Hahn, D.A., Krueger, R.P., and Campbell-Osmundson, Barbara, 1994, Physical, chemical, and biological data for detailed study of irrigation drainage in the Uncompahgre Project area and in the Grand Valley, west-central Colorado, 199192: U.S. Geological Survey Open-File Report 94-110, $146 \mathrm{p}$.

Campbell-Osmundson, Barbara, 1989, Colorado squawfish heavy metal analysis/comparison to rainbow trout samples taken from Hotchkiss National Fish Hatchery: Grand Junction, Colo., U.S. Fish and Wildlife Service, 9 p.

Carlson, C.A., and Muth, R.T., 1989, The Colorado River-Lifeline of the American Southwest in Dodge, D.P., ed., Proceedings of the International Large River Symposium (LARS): Canadian Special Publication of Fisheries and Aquatic Sciences 106, p. 220-239.

Colburn, Theo, 1981, Aquatic insects as measures of trace element presence - Cadmium and molybdenum: Gunnison, Colo., Western State College, Master's thesis, $157 \mathrm{p}$.
Colorado Department of Health, 1975, The upper Gunnison River drainage: Denver, $70 \mathrm{p}$.

Colorado Department of Health, 1976, Report on the investigation of the water quality of the Colorado River, Dotsero, Colorado, to Utah border: Denver, $17 \mathrm{p}$., plus appendix.

Colorado Division of Wildlife, 1975, Fish and Wildlife analysis for the Dallas Creek Water Project: Denver, $225 \mathrm{p}$.

Cope, O.B., 1977, Index to fishery publications of the Colorado Division of Wildlife: Colorado Division of Wildlife Report DOW-R-D-8-77, 100 p.

Cudlip, Lynn, 1992, High Country Citizens' Alliance water quality report, 1991-1992: Crested Butte, Colo., High Country Citizens Alliance, 22 p., plus appendix.

Cudlip, L.S., French, R.D., and Hickman, Don, 1987, Blue Mesa Reservoir, Colorado-A historical review of its limnology, 1965-1985: Bureau of Reclamation Report REC-ERC-87-3, $59 \mathrm{p}$.

Driver, N.E., 1994, National Water-Quality Assessment Program-Upper Colorado River Basin: U.S. Geological Survey Open-File Report 94-102, 2 p. [Water Fact Sheet]

Dufford, R.G., Zimmerman, H.J., Cline, L.D., and Ward, J.V., 1987, Responses of epilithic algae to regulation of Rocky Mountain streams, in Craig, J.F., and Kemper, J.B., eds., Regulated streams-Advances in ecology: New York, Plenum Press, p. 383-390.

Everhart, W.H., and Seaman, W.R., 1971, Fishes of Colorado: Denver, Colorado Game, Fish and Parks Division, 75 p.

Feast, C.N., 1954, Project report-Grand Lake, Shadow Mountain Reservoir and Granby Reservoir fish management investigations: Denver, Colorado Department of Game and Fish, $24 \mathrm{p}$.

Federal Water Pollution Control Administration, 1968, A report on biological studies of selected reaches and tributaries of the Colorado River: Federal Water Pollution Control Administration Report PR-15, 166 p.

Finnell, L.M., 1961-63, Granby Reservoir fish management studies: Denver, Colorado Department of Game and Fish Job Progress Report, 1961-62 (1 v.), 27 p.; 1963, $17 \mathrm{p}$.

Flinckinger, S.A., Norton, V.C., and Brandau, W.F., 1973, Further aquatic biology investigations on Parachute Creek and tributaries, environmental impact analysis, appendix 10: Parachute, Colo., Atlantic Richfield Company, $65 \mathrm{p}$.

Four Corners Environmental Research Institute, 1976, Biological and chemical studies of selected reaches and tributaries of the Colorado River in the State of Colorado: Denver, Colorado Department of Health, $103 \mathrm{p}$. 
Goettl, J.P., Jr., 1970, Water pollution studies: Denver, Colorado Department of Game, Fish, and Parks, Federal Aid Project F-33-R-6, 130 p.

Goettl, J.P., Jr., and Davies, P.H., 1975, Water pollution studies: Denver, Department of Natural Resources and Colorado Division of Wildlife, Federal Aid Project F-33-R-10, Job Progress Report, 33 p.

Goettl, J.P., Jr., and Davies, P.H., 1978, Water pollution studies: Fort Collins, Colorado Division of Wildlife, Federal Aid Project F-33-R-13, 5 p.

Goettl, J.P., Jr., and Davies, P.H., 1979, Water pollution studies: Denver, Department of Natural Resources and Colorado Division of Wildlife, Federal Aid Project F-33-R-14, Job Progress Report, 43 p.

Goettl, J.P., Jr., and Sinley, J.R., 1970, Water pollution studies: Denver, Colorado Department of Game Fish and Parks, Federal Aid Project F-33-5, 59 p.

Goettl, J.P., Jr., Sinley, J.R., and Davies, P.H., 1972, Water pollution studies: Denver, Department of Natural Resources and Colorado Division of Wildlife, Federal Aid Project F-33-R-7, Job Progress Report, 47 p.

Gurtz, M.E.,1994, Design of biological components of the National Water-Quality Assessment (NAWQA) program, in chap. 15 of Loeb, S.L., and Spacie, Anne, eds., Biological monitoring of aquatic systems: Boca Raton, Fla., Lewis Publishers, p. 323-354.

Hawkins, J.A., and Nesler, T.P., 1991, Nonnative fishes of the Upper Colorado River Basin-An issue paper: Fort Collins, Colorado Division of Wildlife, $72 \mathrm{p}$.

Haynes, C.M., Lytle, T.A., Wick, E.J., and Muth, R.T., 1984, Larval Colorado squawfish Ptychocheilus lucius in the Upper Colorado River Basin, Colorado, USA, 1979-1981: Southwestern Naturalist, v. 29, no. 1, p. 21-34.

Haynes, C.M., and Muth, R.T., 1982, Identification of habitat requirements and limiting factors for Colorado squawfish and humpback chubs: Denver, Colorado Division of Wildlife, Federal Aid Project Progress Report SE-4, 21 p.

Haynes, C.M, and Muth, R.T., 1984, Identification of habitat requirements and limiting factors for Colorado squawfish and humpback chubs: Denver, Colorado Division of Wildlife, Federal Aid Project Progress Report SE-3, 21 p.

Haynes, C.M., Muth, R.T., and Nesler, T.P., 1985, Identification of habitat requirements and limiting factors for Colorado squawfish and humpback chubs: Denver, Colorado Division of Wildlife, Federal Aid in Fish and Wildlife Restoration, Job Final Report, $62 \mathrm{p}$.

Haynes, C.M., Muth, R.T., and Wycoff, L.C., 1982, Range extension for the Redside shiner, Richardonius balteatus (richardson), in the Upper Colorado River drainage: Southwestern Naturalist, v. 27, no. 2, p. 223.
Hickman, T.J., 1983, Effects of habitat alteration by energy resource developments in the Upper Colorado River Basin on endangered fishes, in Adams, V.D., and Lamarra, V.A., eds., Aquatic resources management of the Colorado River ecosystem, proceedings of the 1981 symposium, Las Vegas, Nevada, November 16-18, 1981: Ann Arbor, Mich., Ann Arbor Science Publishers, p. 537-550.

Holden, P.B., 1968, Systematic studies of the genus Gila (Cyprinidae) of the Colorado River Basin: Logan, Utah State University, Master's thesis, 67 p.

Holden, P.B., 1977, Habitat requirements of juvenile Colorado River squawfish: U.S. Fish and Wildlife Service Report FWS/OBS-77/65, 71 p.

Holden, P.B., Richards, Carl, Crist, L.W., and Campbell, J.R., 1981, Aquatic biology studies for proposed Colorado-Ute Electric Association power plant near Grand Junction, Colorado: Logan, Utah, Bio/West, Inc., Report PR 56-1, 66 p.

Holden, P.B., and Stalnaker, C.B., 1975, Distribution and abundance of mainstream fishes of the middle and Upper Colorado River Basins, 1967-1973: American Fisheries Society Transactions, v. 104, p. 217-231.

Horn, Barbara, 1990, Interim report on the biological assessment of the Eagle River Superfund Site, Eagle County, Colorado, 1990: Denver, Colorado Division of Wildlife, 13 p.

Horn, Barbara, and Woodling, John, 1991, Final report, biological monitoring assessment, Eagle River Superfund Site, Eagle County, Colorado for 1990 sampling (April and September): Denver, Colorado Division of Wildlife, $17 \mathrm{p}$.

Hurlbut, S.C., 1990, Effects of heavy metals on benthic macroinvertebrate communities in two high-elevation streams, Colorado Front Range: Golden, Colorado School of Mines, Master's thesis, $80 \mathrm{p}$.

Joseph, T.W., Sinning, J.A., Behnke, R.J., and Holden, P.B., 1977, An evaluation of the status, life history, and habitat requirements of endangered and threatened fishes of the Upper Colorado River system: U.S. Fish and Wildlife Service Report FWS/OBS-77/62, 184 p.

Kaeding, L.R., and Osmundson, D.B., 1989, Biologically defensible flow recommendations for the maintenance and enhancement of Colorado squawfish habitat in the 15-mile reach of the Upper Colorado River during July, August, and September: Grand Junction, Colo., U.S. Fish and Wildlife Service, $169 \mathrm{p}$.

Kidd, G.T., 1977, An investigation of endangered and threatened fish species in the Upper Colorado River as related to Bureau of Reclamation projects: Clifton, Colo., Northwest Fisheries Research, 37 p. 
Kinnear, B.S., and Vincent, R.E., 1967, Fishes of the Black Canyon of the Gunnison National Monument (completion report to U.S. National Park Service): Fort Collins, Colorado State University, 45 p.

Kittel, Gwen, Rondeau, Renee, Lederer, Nan, and Randolph, Dan, 1994, A classification of the riparian vegetation of the White and Colorado River Basins, Colorado: Boulder, Colorado Natural Heritage Program, $166 \mathrm{p}$.

Knight, A.W., 1965, Studies of the stoneflies (Plecoptera) of the Gunnison River drainage in Colorado: Salt Lake City, University of Utah, Ph.D. dissertation, $155 \mathrm{p}$.

Knight, A.W., and Argyle, D.W., 1962, Limited limnological studies of the Gunnison River, Colorado: Salt Lake City, University of Utah, Anthropological Papers 59, Upper Colorado Series 8, p. 136-149.

Krueger, R.P., 1988, Heavy metal analysis of seven Colorado squawfish from the Colorado and White Rivers: Grand Junction, Colo., U.S. Fish and Wildlife Service, $4 \mathrm{p}$.

Krueger, Richard, Thompson, Andrew, and CampbellOsmundson, Barbara, 1991, Big river fishesEnvironmental contaminants in fish species used as surrogates for threatened and endangered fish of the Colorado River Basin, interim report: Grand Junction, Colo., U.S. Fish and Wildlife Service and Wildlife Enhancement, $13 \mathrm{p}$.

Kunkle, Sam, Nickerson, Randy, Smillie, G.M., and Andrascik, Roger, 1983, Metal concentrations in fish at Curecanti National Recreation Area, Gunnison, Colorado: Fort Collins, Colo., U.S. Department of the Interior National Park Service, Water Resources Field Support Laboratory Report 83-3-P, 33 p.

Kurey, W.J., 1985, Organochlorine contaminants in fish of the Grand Valley: Grand Junction, Colo., U.S. Fish and Wildlife Service, 11 p., plus appendices.

Leahy, P.P., Rosenshein, J.S., and Knopman, D.S., 1990, Implementation plan for the National Water-Quality Assessment Program: U.S. Geological Survey Open-File Report 90-174, $10 \mathrm{p}$.

Lemons, D.G., 1954, A field survey of western Colorado streams and lakes: Denver, Colorado Department of Game and Fish, 29 p.

Maddux, H.R., Fitzpatrick, L.A., and Noonan, W.R., 1993, Colorado River endangered fishes critical habitat, draft biological support document: Salt Lake City, Utah, U.S. Fish and Wildlife Service, 225 p.

Mars, J.P., 1979a, Water quality investigations of the Fraser River, September 1977 through January 1978: Denver, Colorado Department of Health, Water Quality Control Division, 27 p.
Mars, J.P., 1979b, Water quality investigations of Gore Creek, August 1977 through January 1978: Denver, Colorado Department of Health, Water Quality Control Division, $20 \mathrm{p}$.

Martin, Lori, and Prestel, Mary, 1991, Annual report on the biological assessment of the Eagle River Superfund Site, Eagle County, Colorado, 1991: Denver, Colorado Division of Wildlife, $21 \mathrm{p}$.

McAda, C.W., 1977, Aspects of the life history of three Catostomids native to the Upper Colorado River Basin: Logan, University of Utah, Master's thesis, $117 \mathrm{p}$.

McAda, C.W., Bates, J.W., Cranney, J.S., Chart, T.E., Elmbad, W.R., and Nesler, T.P., 1994, Interagency standardized monitoring program - Summary of results, 1986-1992; recovery implementation program for the endangered fishes of the Upper Colorado River Basin: Denver, U.S. Fish and Wildlife Service, 73 p.

McAda, C.W., and Kaeding, L.R., 1989, Relations between maximum-annual river discharge and the relative abundance of age-0 Colorado squawfish in the Upper Colorado River, final report: Grand Junction, Colo., U.S. Fish and Wildlife Service, 25 p.

McAda, C.W., and Kaeding, L.R., 1991a, Physical changes in the Gunnison and Colorado Rivers resulting from construction of the Aspinall Unit and related projects, with hypothesis to assess the effects on the endangered fishes, final report: Grand Junction, Colo., U.S. Fish and Wildlife Service, $60 \mathrm{p}$.

McAda, C.W., and Kaeding, L.R., 1991b, Movements of adult Colorado squawfish during the spawning season in the Upper Colorado River, Transactions of American Fisheries Society, v. 120, p. 1339-1345.

McAda, C.W., and Wydoski, R.S., 1980, The razorback sucker, Xyrauchen texanus, in the Upper Colorado River Basin, 1974-76: Grand Junction, Colo., U.S. Fish and Wildlife Service Technical Paper 99, $50 \mathrm{p}$.

McKnight, D.M., and Feder, G.L., 1984, The ecological effect of acid conditions and precipitation of hydrous metal oxides in a Rocky Mountain stream: Hydrobiologia, v. 119, no. 2, p. 129-138.

Meador, M.R., and Gurtz, M.E., 1994, Biology as an integrated component of the U.S. Geological Survey's National Water-Quality Assessment Program: U.S. Geological Survey Open-File Report 94-83, 4 p. [Water-Resources Notes]

Miller, W.H., Tyus, H.M., and Carlson, C.A., eds., 1982, Fishes of the Upper Colorado system-Present and future: Bethesda, Md., Western Division of the American Fisheries Society, 131 p. 
Natural Energy Resources Company, 1987, Report on fish, wildlife, and botanical resources: Denver, Colo., Appendix E1 [Report on Water Use and Quality], variously paged.

Nehring, R.B., 1980, Stream fishery investigations: Fort Collins, Colorado Division of Wildlife, Federal Aid F-51-R-5, Job Progress Report, 161 p.

Nehring, R.B., 1986, Stream fisheries investigations: Fort Collins, Colorado Division of Wildlife, Federal Aid Project F-51-R, Job Progress Report, 124 p.

Nehring, R.B., 1987, Stream fisheries investigations: Fort Collins, Colorado Division of Wildlife, Federal Aid Project F-51-R, Job Final Report, 118 p.

Nehring, R.B., 1993, Stream fisheries investigations: Fort Collins, Colorado Division of Wildlife Federal Aid Project F-51, Job Final Report, 97 p.

Nehring, R.B., and Anderson, R.M., 1983, Stream fisheries investigations: Fort Collins, Colorado Division of Wildlife, Federal Aid Project F-51-R, Job Progress Report, $186 \mathrm{p}$.

Nehring, R.B., and Anderson, R.M., 1993, Determination of population-limiting critical salmonid habitats in Colorado streams using the physical habitat simulation system: Rivers, v. 4, no. 1, p. 1-19.

Nehring, R.B., and Thompson, K.G., 1994, Stream fisheries investigations: Fort Collins, Colorado Division of Wildlife, Federal Aid Project F-51, Job Progress Report, $53 \mathrm{p}$.

Nelson, M.S., and Roline, R.A., 1995, Impacts of sediment in the Gunnison River, Colorado, on macroinvertebrate communities: Bureau of Reclamation Technical Memorandum 8220-95-5, [variously paged].

NUS [Nuclear Utilities Service] Corporation, 1981, Biological/water-quality evaluation related to Colorado stream classification: Denver, NUS Report 3925, 18 p.

Olive, J.R., 1953, A bibliography of the limnology and fishery biology of Colorado: Denver, Colorado Department of Game and Fish, $37 \mathrm{p}$.

Osmundson, B.C., 1992, Inorganic elements detected in sediments and aquatic biota from the Uncompahgre River and Ridgway Reservoir, Colorado, 1987-1990: Grand Junction, Colo., U.S. Fish and Wildlife Service Contaminants Report R6/303J/92, 42 p.

Osmundson, D.B., and Kaeding, L.R., 1989, Studies of Colorado squawfish and razorback sucker use of the '15-mile reach' of the Upper Colorado River as part of conservation measures for the Green Mountain and Ruedi Reservoir water sales, final report: Grand Junction, Colo., U.S. Fish and Wildlife Service, $85 \mathrm{p}$.
Osmundson, D.B., and Kaeding, L.R., 1991, Recommendations for flows in the 15-mile reach during OctoberJune for maintenance and enhancement of endangered fish populations in the Upper Colorado River, final report: Grand Junction, Colo., U.S. Fish and Wildlife Service, Colorado River Fishery Project, 82 p. [Available from National Technical Information Service, Springfield, VA 22161 as NTIS Report PB-92 106 061/XAB.]

Osmundson, D.B., Nelson, P., Fenton, K., and Ryden, D.W., 1995, Relationships between flow and rare fish habitat in the '15-mile reach' of the Upper Colorado River, final report: Grand Junction, Colo., U.S. Fish and Wildlife, Colorado River Fishery Project, 71 p. and appendices.

Peckarsky, B.L., 1983, Report to the Sierra Club-Water quality of the upper East River and Copper Creek, Gunnison County, Colorado: Ithaca, N.Y., Cornell University, 6 p.

Pennack, R.W., 1974, Limnological status of streams, summer 1973, Piceance Basin, Rio Blanco and Garfield Counties: Boulder, Colo., Thorne Ecological Institute Ross-25, $50 \mathrm{p}$.

Pettus, David, 1974, Inventory and impact analysis of fishes, Piceance Creek Basin, Rio Blanco and Garfield Counties, Colorado: Boulder, Colo., Thorne Ecological Institute Ross-25, 13 p.

Pitlick, John, and Van Steeter, Mark, 1994, Changes in morphology and endangered fish habitat of the Colorado River: Fort Collins, Colorado State University, Colorado Water Resources Research Institute Completion Report 188, 24 p.

Pratt, H.P., 1938, Ecology of the trout of the Gunnison River: Boulder, University of Colorado, Ph.D. dissertation, $197 \mathrm{p}$.

Prestel, Mary, 1992, Annual report on the biological assessment of the Eagle River Superfund Site, Eagle County, Colorado, 1992: Denver, Colorado Division of Wildlife, $27 \mathrm{p}$.

Prewitt, C.G., Wick, E.J., Snyder, D.E., and Langlois, David, 1978, Colorado squawfish and humpback chub population and habitat monitoring, 1977-1978: Denver, Colorado Division of Wildlife, Federal Aid to Endangered Wildlife, Job Progress Report SE-3-1, $57 \mathrm{p}$.

Richardson, J.W., Jr., 1962, A stream survey of East Elk Creek, Gunnison River, Colorado: Salt Lake City, University of Utah, Anthropological Papers 59, Upper Colorado Series 8, p. 152-156.

Rosenland, B.D., and Stevens, D.R., 1988, Fisheries and aquatic management, Rocky Mountain National Park, 1987 [annual report]: Golden, Colo., U.S. Fish and Wildlife Service and National Park Service, 99 p., plus appendix. 
Rosenland, B.D., and Stevens, D.R., 1990, Fisheries and aquatic management, Rocky Mountain National Park, 1989-1990 [annual report]: Golden, Colo., U.S. Fish and Wildlife Service and National Park Service, $188 \mathrm{p}$.

Ruiter, D.E., and Bishop, M.B., 1984, Surface water hydrology, water quality, and aquatic life of the Colorado-Utah oil shale region-A data summary (final report): U.S. Environmental Protection Agency Report 908/3-84/002, 891 p. [Available from National Technical Information service, Springfield, VA 22161 as NTIS Report PB-85 169 225.]

Stanford, J.A., 1994, Instream flows to assist the recovery of endangered fishes of the Upper Colorado River Basin: U.S. Department of the Interior, National Biological Survey, Biological Report 24, $47 \mathrm{p}$.

Stanford, J.A., and Ward, J.V., 1986, Fish of the Colorado system, in Davies, B.R., and Walker, K.F., eds., The ecology of river systems: Boston, W. Junk Publishers, p. $385-402$.

Tyus, H.M., Burdick, B.D., Valdez, R.A., Haynes, C.M., Lytle, T.A., and Berry, C.R., 1982, Fishes of the Upper Colorado River Basin-Distribution, abundance, and status, in Miller, W.H., Tyus, H.M., and Carlson, J.A., eds., Fishes of the Upper Colorado River system-Present and future; proceedings of a symposium presented at the annual meeting of the American Fisheries Society in Albuquerque, New Mexico, September 18, 1981: Bethesda, Md., Western Division of the American Fishery Society, p. 12-18, 64-70.

U.S. Fish and Wildlife Service, 1987, Recovery implementation program for endangered fish species in the Upper Colorado River Basin-Environmental assessment: Denver, U.S. Fish and Wildlife Service, [variously paged].

U.S. Public Health Service, 1963, Radiological content of Colorado River Basin bottom sediments, August 1960-August 1961: U.S. Department of Health, Education, and Welfare, Public Health Service Report PR-10, 62 p. [Available from National Technical Information Service, Springfield, VA 22161 as NTIS Report PB-260 216/7.]

Valdez, R.A., and Clemmer, G.H., 1982, Life history and prospects for recovery of the humpback chub and bonytail chub, in Miller, W.H., Tyus, H.M., and Carlson, C.A., eds., Fishes of the Upper Colorado River system-Present and future: Bethesda, Md., Western Division of the American Fisheries Society, p. $109-119$.

Ward, J.V., 1987, Trichoptera of regulated Rocky Mountain streams: Series Entomologica, v. 39, p. 375-380.

Ward, J.V., and Kondratieff, B.C., 1992, An illustrated guide to the mountain stream insects of Colorado: Niwot, University Press of Colorado, 191 p.
Ward, J.V., and Stanford, J.A., 1990, Ephemeroptera of the Gunnison River, Colorado, U.S.A., in Campbell, I.C., ed., Mayflies and stoneflies - Life history and biology; proceedings of the 5 th international ephemeroptera conference and the 9th international plecoptera conference: Boston, Kluwer Academic Publishers, p. 215-220.

Ward, J.V., Zimmerman, H.J., and Cline, L.D., 1986, Lotic zoobenthos of the Colorado System, in Davies, B.R., and Walker, K.F., eds., The ecology of river systems: Boston, W. Junk Publishers, p. 403-423.

Weber, D.T., 1959, Effects of reduced stream flows on the trout fishery below Granby Dam, Colorado: Fort Collins, Colorado State University, Master's thesis, $149 \mathrm{p}$.

Wick, E.J., Hawkins, J.A., and Carlson, C.A., 1985, Colorado squawfish population and habitat monitoring, 1983-1984: Fort Collins, Colorado Division of Wildlife and Colorado State University, Final Report SE-3-7, 48 p.

Wick, E.J., Hawkins, J.A., and Carlson, C.A., 1986, Colorado squawfish population and habitat monitoring, 1983-1984: Fort Collins, Colorado Division of Wildlife and Colorado State University, Final Report SE-3-8, 80 p.

Wick, E.J., Lytle, T.A., and Haynes, C.M., 1981, Colorado squawfish and humpback chub population and habitat monitoring, 1979-1980: Denver, Colorado Division of Wildlife, Federal Aid to Endangered Wildlife, Job Progress Report SE-3-3, $156 \mathrm{p}$.

Wick, E.J., Snyder, D.E., Langlois, David, and Lytle, T.A., 1979, Colorado squawfish and humpback chub population and habitat monitoring: Denver, Colorado Division of Wildlife, Federal Aid to Endangered Wildlife, Job Progress Report SE-3-2, 57 p.

Wiltzius, W.J., 1978, Some factors historically affecting the distribution and abundance of fishes in the Gunnison River, final report to Bureau of Reclamation, Upper Colorado region, Salt Lake City, Utah: Fort Collins, Colorado Division of Wildlife, 194 p., plus appendix.

Woodling, John, 1976, Pollution of the Slate River via a mine discharge and sewage treatment plant effluents-Report for Water Quality Control Division: Denver, Colorado Department of Health, Water Quality Control Division, $20 \mathrm{p}$.

Woodling, John, 1977, Chemical and physical aspects of the Roan Creek ecosystem, 1975-1976: Denver, Colorado Department of Health, Water Quality Control Division, $30 \mathrm{p}$.

Woodling, John, 1985, Colorado's little fish, a guide to the minnows and other lesser known fishes in the State of Colorado: Denver, Colorado Division of Wildlife, $77 \mathrm{p}$. 
Woodling, John, 1993, Annual report on the biological assessment of the Eagle River Superfund Site, Eagle River, Colorado, 1993: Denver, Colorado Division of Wildlife, $14 \mathrm{p}$.

Wuerthele, Mark, 1976, Water quality survey of the Eagle River Basin, 1975: Denver, Colorado Department of Health, Water Quality Control Division, $101 \mathrm{p}$. 